\title{
De los principios del Derecho Obligacional y Contractual contemporáneo
}

\author{
On the Principles of the Law of Obligations and the Contemporary \\ Contractual Law \\ Dos princípios do Direito Obrigacional e Contratual contemporâneo
}

\section{Luis ARmando Tolosa VillabonA*}

FECHA DE RECEPCIÓN: 24 DE MARZO DE 2017. FECHA DE ACEPTACIÓN: 17 DE ABRIL DE 2017

DOI: http://dx.doi.org/10.12804/revistas.urosario.edu.co/sociojuridicos/a.5701

Para citar este artículo: Tolosa, L. A. (2017). De los principios del Derecho Obligacional y Contractual contemporáneo. Estudios Socio-Jurídicos, 19(2), 13-61. Doi: http://dx.doi.org/10.12804/revistas.urosario.edu.co/sociojuridicos/a.5701

\section{RESUMEN}

Este artículo se ocupa del análisis de algunos principios hermenéuticos esenciales cuyo alcance normativo define el ejercicio racional de las relaciones obligatorias y, en consecuencia, las contractuales, así como las extrancontractuales, en un mundo globalizado. El análisis está construido desde una visión constitucionalista del derecho privado que enarbola los postulados del Estado Constitucional y Social de Derecho y el avance del Derecho internacional en la regulación de las operaciones económicas y comerciales. Estos principios constituyen un marco jurídico esencial para garantizar el equilibrio y la equidad en las relaciones económicas, evitando los excesos de los grupos económicos fuertes o de los sujetos del vínculo obligacional o contractual situados en posición dominante o de preeminencia sobre el otro, abogando por un equilibrio contractual real, favoreciendo la protección de los derechos del consumidor en la totalidad del ciclo económico, en un contexto de aprovechamiento racional de los recursos naturales en forma incluyente, solidaria y humanizada.

Palabras clave: Estado Social de Derecho, constitución económica y ambiental, Derecho obligacional, solidaridad social, equilibrio contractual, derechos del consumidor, responsabilidad, derecho de daños, buena fe, deberes primarios y secundarios, teoría del acto propio.

* Magistrado actual de la Corte Suprema de Justicia de Colombia, sala de Casación Civil; exmagistrado de los Tribunales Superiores de Riohacha (Guajira) y Tunja (Boyacá); abogado, licenciado en Educación, Filosofía y Letras; magíster en Derecho Procesal y en Modelos de Enseñanza Problémica; especialista en Derecho Público, Instituciones Jurídico Familiares, Derecho Económico Privado, Derecho Procesal Constitucional, Derecho Comercial, Derecho Penal y Criminología. Actualmente profesor de la Universidad Colegio Mayor del Rosario en el área de Derecho Civil - Obligaciones y de la especialización de Derecho Procesal. Correo electrónico: latovilla@hotmail.com 


\section{ABSTRACT}

This paper analyses some hermeneutic principles whose normative scope defines the rational exercise of mandatory relationships and, as a consequence, contractual and extracontractual relationships. This analysis is built from a constitutional view of private law, which emphasizes in postulates of the Constitutional and Social Law State and the advancement of International Law on regulation of economic and commercial transactions. In a context of rational use of natural resources, those principles constitute the legal framework to ensure balance and equity in economic relationships, by preventing excesses of strong economic groups - or those contractual subjects in a dominant position- and favoring the protection of consumer rights along the business cycle.

Keywords: Rule of Law, economic and environmental constitution, Civil Law, social solidarity, contractual balance, consumer rights, Tort Law, good faith, self-acts theory.

\section{RESUMO}

Este artigo ocupa-se da análise de alguns princípios hermenêuticos essenciais cujo alcance normativo define o exercício racional das relações obrigatórias e por consequência as contratuais, assim como as extracontratuais em um mundo hoje globalizado. A análise está construída desde uma visão constitucionalista do direito privado que arvora os postulados do Estado Constitucional e Social de Direito e o avanço do Direito Internacional na regulação das operações económicas e comerciais. Estes princípios constituem um marco jurídico essencial para garantir o equilíbrio e a equidade nas relações económicas, evitando os excessos dos grupos económicos fortes ou dos sujeitos do vínculo obrigacional ou contratual situados em posição dominante ou de preeminência sobre o outro, advogando por um equilíbrio contratual real, favorecendo a proteção dos direitos do consumidor na totalidade do ciclo económico, em um contexto de aproveitamento racional dos recursos naturais em forma inclusiva, solidária e humanizada.

Palavras-chave: Estado Social de Direito, constituição económica e ambiental, Direito obrigacional, solidariedade social, equilíbrio contratual, direito do consumidor, responsabilidade, direito de danos, boa-fé, deveres primários e secundários, e teoria do ato próprio. 


\section{Introducción}

El Derecho Obligacional ha alcanzado una compleja pero positiva evolución en pro de una humanización creciente. Ha transitado desde el esquema de la venganza privada fincado primero en el Código de Hammurabi y luego en las normas decenvirales o de las XII Tablas, al desarrollo de nuevos principios que orientan todo el ámbito del Derecho Privado contemporáneo con incidencia directa e integral en las fuentes obligacionales, especialmente en el marco contractual y en el derecho extracontractual o de daños. Se trata de un progreso vertiginoso compelido en lo jurídico, especialmente hoy, por la nueva forma de Estado democrático, signado como Estado Constitucional y Social de Derecho y por el avance del Derecho Internacional en la regulación de las operaciones económicas y comerciales en procura del bienestar de todos los habitantes de la tierra y de la consolidación de nuevas relaciones sociales, culturales, políticas y económicas.

El Estado interviene a fin de racionalizar el poder del acreedor en la relación contractual, no tanto para actuar por lástima al deudor, sino para controlar los excesos y abusos de poder del acreedor sobre las impotentes masas de usuarios (como es el caso de los derechos del consumidor), para procurar el equilibrio y la equidad entre las partes contratantes y proteger al usuario como parte débil frente al proveedor del bien o servicio o, en el caso de los hechos dañosos, buscar la prevención o el resarcimiento de las víctimas o damnificados en forma integral.

Este artículo analiza algunos principios jurídicos que, desde diferentes tópicos, defienden un ejercicio racional de las relaciones obligatorias, contractuales y extrancontractuales. El trabajo se desarrolla a partir de una visión constitucionalista del derecho privado que abandera los postulados del Estado Constitucional y Social de Derecho y atiende a la evolución del Derecho Económico Internacional. Estos principios representan un cuerpo normativo fundamental en el amparo del equilibrio y la equidad en las relaciones económicas, evitando los excesos de los grupos económicos fuertes y favoreciendo la protección de los derechos del consumidor, desde una perspectiva de disposición racional de los recursos naturales. 


\section{La constitucionalización y publicitación creciente del Derecho Privado en los sistemas jurídicos nacionales}

La autonomía de la voluntad es la columna vertebral del Derecho Privado en las familias del civil law y del common law, además, permea y recorre toda la tradición continental. Como principio, implica que dentro del poder regulatorio de las relaciones jurídicas patrimoniales, lo contratado, acordado o concertado por las partes o por los sujetos de la relación obligatoria es expresión de la libertad humana, ejercida, por supuesto, en las fronteras o límites que la ley impone, especialmente entre las disposiciones de carácter imperativo y las de índole dispositiva. Se obliga a quien otorga su voluntad en forma expresa o tácita, mediante el acto o negocio jurídico seleccionado y autorizado por el ordenamiento. Las partes ejercen sus derechos mediante las instituciones jurídicas que consideren pertinentes para satisfacer sus intereses, utilizando formas típicas o atípicas y regulando cuanto permita el ordenamiento, como en el caso de tasaciones indemnizatorias anticipadas, arras, ejecución obligacional, e, inclusive, autorizando señalar cláusulas compromisorias o arbitrales y múltiples aspectos convencionales. Sin embargo, la autonomía de la voluntad como ejercicio de la libertad no puede afectar el ordenamiento público ni eludir el cumplimiento de normas constitucionales, las cuales hoy ejercen una influencia particular.

El efecto envolvente del Derecho Constitucional, por contera, implica cerrar la brecha de la perjudicial y tajante separación entre Derecho Privado y Derecho Público que significó deshumanizar por centurias la relación obligatoria y la contratación y, al mismo tiempo, se tradujo en el envilecimiento de los derechos del usuario, del deudor, pero también los de la víctima en el marco de la responsabilidad, creando dos saberes jurídicos separados y marginando del marco del Derecho Civil y Comercial a la Constitución, el bloque de constitucionalidad y los tratados internacionales sobre derechos humanos. De esta manera, el Derecho Obligacional no escapa ni debe escapar al influjo del Derecho Constitucional'

1 Hoy la incidencia del neoconstitucionalismo en el Derecho Obligacional supera la imaginación de los clásicos, para quienes lo determinante era el principio de autonomía anclado en la intención de las partes. Sin embargo, el sobreconstitucionalismo puede conllevar riesgos e inseguridad jurídica porque las normas constitucionales someten la voluntad del sujeto que 


\section{La construcción de un Derecho obligacional articulado con la Constitución Económica}

En el contexto actual resulta primordial comprender que el sistema jurídico obligacional se perfecciona e impregna in integrum en el marco constitucional pero en forma directa y esencial con la Constitución Económica del Estado Social y Democrático de Derecho. En este sentido, los principios, criterios y fundamentos de la obligación, sus clases, sus fuentes, sus efectos, la transmisión y sus formas extintivas, así como toda la teoría y práctica del acto jurídico y de la autonomía de la voluntad, la teoría del daño y, en general, todas las instituciones jurídicas anexas al vínculo obligacional como los regímenes indemnizatorios y reparatorios, deben proyectar los propósitos, los valores y los principios del estatuto teórico de la Constitución Económica para desarrollar los estándares materiales de una democracia real. Siguiendo a la Corte Constitucional colombiana, se entiende por Constitución Económica:

[...] la parte del Texto Fundamental que sienta los principios superiores que orientan y fundan la posición del Estado en relación con la economía y los derechos de los asociados en este mismo ámbito. A juicio de la Corte, dicha parte de la Constitución, se encuentra compuesta por: [...] las normas constitucionales que ordenan la vida económica de la sociedad y establecen el marco jurídico esencial para la estructuración y funcionamiento de la actividad material productiva, señalando los fundamentos esenciales que deberán tener en cuenta los operadores económicos (Corte Constitucional de Colombia, Sentencia C-265 de 1994).

se obliga y muchas veces se tornan en disposiciones imperativas y hermenéuticas con carácter vinculante que modifican las convenciones, pudiendo eventualmente, invalidar un contrato. Simultáneamente, la fuerza que toma el precedente en las corrientes del derecho continental también socava la seguridad jurídica de la contratación, dado el carácter dinámico y variable que muchas veces media en los pronunciamientos de los tribunales constitucionales sometidos a los vaivenes políticos. En Colombia, por ejemplo, en virtud de la doctrina constitucional, el impacto del precedente en el quehacer jurídico es arrollador: las sentencias C-131 y C-113 de 1993, C-037 de 1996, C-083 de 1995; C-037 de 2000, C-836 de 2001, T-292 de 2006, C-335 de 2008, C-634 y C-539 de 2011, todas ellas de la Corte Constitucional colombiana. 
Según el artículo 335 de la Carta Constitucional colombiana de 1991, la actividad financiera y bursátil puede ser objeto de intervención y es función y objetivo constitucional del Estado propender por la democratización del crédito para impedir abusos frente a los usuarios del sistema financiero, y, por supuesto, también frente a los consumidores.

Los modelos económicos de libre competencia y de protección de la autonomía privada en el Estado Democrático de Derecho, demandan de las autoridades estatales, y de los jueces en particular, superar las percepciones individualistas del Estado legislativo para imponer el equilibrio y la equidad en las relaciones económicas, la oferta de bienes y servicios, la fijación de precios, el intercambio de bienes y las transacciones comerciales, interviniendo en el control de las fuerzas económicas y ante los excesos de los grupos económicos fuertes. Ello pone en evidencia la necesidad de reformular las reglas de la formación del contrato, sobre todo en la contratación masiva, vigorizando la posibilidad del contratante débil de reflexionar y arrepentirse y robusteciendo el régimen de responsabilidad del contratante fuerte y, al titular de la información mediante medidas legislativas y criterios jurisprudenciales, que respondan a la nueva estructura del Estado Constitucional y Social de Derecho.

\section{Cimentación y fundamentación de un Derecho obligacional y contractual en la protección del medio ambiente y el hábitat universal}

La defensa y protección del ambiente deben estar incorporadas necesariamente en las propias constituciones y en los diferentes códigos que integran la estructura del Estado, de tal forma que la teoría obligacional no puede prescindir de la tarea de respeto y protección del modus vivendi ecológico mundial ni omitir la conservación de los recursos naturales por tratarse de un elemento capital e insustituible para quienes participan en las relaciones jurídicas como presupuesto para la estabilidad de estas y la coexistencia de todos los sujetos de la obligación. Como corolario, la relación obligatoria, los negocios comerciales de todos los seres humanos $\mathrm{y}$, en general, las relaciones jurídicas y económicas no pueden verse en 
forma aislada como transacciones iusprivatistas, sino dentro del inevitable marco de la humanidad y del entorno natural que las rodea.

En la actualidad, cobran mayor interés las temáticas relacionadas con el medio ambiente, ante la potente y decisiva incidencia que juegan los bienes colectivos por su indivisibilidad y uso común, para el aseguramiento de los derechos subjetivos individuales. El éxito, la eficacia y finalidad de las relaciones jurídicas no depende exclusivamente de la mera esfera individual sino también de la social y ambiental. Un sujeto jurídico sin oxígeno, agua o un entorno sano, no puede celebrar actos y negocios jurídicos: sin un ambiente saludable no puede existir. De tal forma que los derechos y relaciones jurídicas individuales dependen de la observancia de la Constitución Ambiental y, por consiguiente, cada relación jurídica debe ser observada y respetada, tributándola con cláusulas expresas que la tutelen con normas severas y con conductas que procuren proteger el hábitat natural de todos los seres, preservándolo del creciente deterioro, censurando con nulidad absoluta y eficaces sanciones los actos y negocios jurídicos que directa o indirectamente se encaminen a destruirlo.

En esa dirección, se deben potenciar la preservación de las especies animales y vegetales, la defensa de los ecosistemas, y en general, los intereses de la comunidad relacionados con la protección del medio ambiente. En forma simultánea, se deben plasmar instrumentos idóneos para el ejercicio de los derechos individuales homogéneos para supuestos con causa común cuando afectan pluralidad de derechos y, por supuesto, los propios derechos colectivos.

La comunidad mundial ha venido proyectando, en forma paulatina y creciente, instrumentos jurídicos para la tutela jurídica del hábitat humano. Así, por ejemplo, la Asamblea General de las Naciones Unidas, por medio de la Resolución N. 2398 (XXIII), aprobó la recomendación del Comité Económico para convocar una Conferencia Mundial sobre el punto y declaró a 1970 como el año del medio ambiente. La Conferencia de la ONU en 1972 en Estocolmo (Suecia), realizada entre los días cinco y dieciséis de junio, aprobó trascendentales decisiones para su defensa. El Tratado de Maastricht del siete de febrero de 1992, por medio del cual la entonces Comunidad Económica Europea pasó a denominarse Comunidad Europea, insistió vehementemente en el desarrollo 
de políticas de protección medioambientales, muestra de lo cual fue el posterior Libro Blanco.

El Tratado de Ámsterdam, que modificó el de la Comunidad Europea, dando lugar en 1997 al Tratado de la Unión Europea (UE), señaló como objetivo la defensa del medio ambiente. Asimismo, el Tratado que instituyó la Constitución para Europa en el 2004 proclamó su protección. La Directiva 2004/35/CE demanda la existencia de un sistema de responsabilidad, prevención y reparación del daño ambiental. Las Conferencias Mundiales del Medio Ambiente de Estocolmo y Río en pro de la restauración y conservación de la biosfera contra las actividades peligrosas y contaminantes se encuentran en esa línea ${ }^{2}$. Empero, todos estos instrumentos y esfuerzos siguen siendo letra muerta porque no se traducen en medidas reales que reduzcan el deterioro del ambiente ${ }^{3}$. Los Objetivos del Desarrollo del Milenio (ODM), los Objetivos de Desarrollo Sostenible (ODS), la Conferencia de las Partes de la UNFCCC (COP), el Protocolo de Montreal, el Protocolo de Kioto (que buscó un recorte en las emisiones de $\mathrm{CO}_{2}$ del $15 \%$ para los países firmantes en relación a 1990), incluyendo la Vigésima primera conferencia de las partes de la convención marco de las Naciones Unidas sobre el cambio climático (COP-21 de París), que procura obtener un compromiso vinculante inter-

2 En Colombia, a principios de los años setenta se congregaron alrededor de la construcción del Código de Recursos Naturales y del Medio Ambiente; en los años ochenta lo hicieron en torno a la creación de los consejos verdes en más de 600 municipios y, a principios de los años noventa, en la construcción de la nueva Carta política, que hoy se suele denominar la Constitución Verde, y en la creación del Ministerio de Ambiente y del Sistema Nacional Ambiental.

3 La gravedad del problema se muestra también con la serie interminable, como no otra, de instrumentos internacionales, que procuran la protección del medio ambiente. Además de los relacionados con la temática son los siguientes: La Convención sobre la Diversidad Biológica de Río de Janeiro del cinco de junio de 1992; La Convención Marco de las Naciones Unidas sobre Cambio Climático en Nueva York del 9 de mayo de 1992; El Protocolo a la Convención Marco de Naciones Unidas sobre Cambio Climático de Kyoto de 11 de diciembre de 1997; La Convención para el Control de los Movimientos Transfronterizos de los Desechos Peligrosos y su Eliminación de Basilea, 22 de marzo de 1989; La Convención sobre el Comercio Internacional de Especies Amenazadas de Fauna y Flora Silvestre, Washington, 22 de junio de 1979; La Convención sobre la Protección del Patrimonio Mundial, Cultural y Natural de París de 1972; La Convención de las Naciones Unidas sobre Derecho del Mar, Montenegro de 1982; Protocolo de la Carta de la Organización de Estados Centroamericanos, Tegucigalpa, 1992; El Convenio para la Conservación de la Biodiversidad y Protección de Áreas Silvestres Prioritarias en América Central, Managua, 1992; El Convenio Regional sobre Cambios Climáticos, Guatemala, de 1993; El Acuerdo Regional sobre el Movimiento Transfronterizo de Desechos Peligrosos, Panamá, 1992; Convenio para el Manejo y la Conservación de los Ecosistemas Naturales, Forestales y el Desarrollo de Plantaciones Forestales, Guatemala, 1993, conferencias que inclusive se han prolongado con datas ulteriores. 
nacional, con participación de las grandes potencias, para la reducción de los gases de efecto invernadero y, que con la presencia de alrededor de 195 países y bajo el activo liderazgo del presidente francés de entonces -François Hollande- no pasó de ser una aspiración abstracta. Ahora bien, ha de considerarse que, con no poca frecuencia, estos convenios no son ratificados por las grandes potencias ni por los países causantes de la mayor parte de las emisiones contaminantes. Así, esta última conferencia concluyó con un Acuerdo, no con un Tratado, de modo que poco poder vinculante representa en los propósitos de limitación de producción de gases efectos invernadero que han venido aumentando la temperatura del planeta.

Por lo tanto, las políticas quedan en el marco de lo voluntario, más no de lo forzoso. Se necesitan compromisos políticos, sociales, académicos y éticos, para apostar contra los factores destructores del medio ambiente, porque la cuestión es de supervivencia. Se demanda descarbonizar la producción de electricidad y luchar contra la producción de energía obtenida de combustibles fósiles. Deben acelerarse políticas para mitigar las graves transformaciones de las condiciones ambientales de lo contrario, la humanidad y el hombre como tal, puede tornarse en el pasajero de un planeta que se destruye.

Debe obligarse a los países contaminantes que reduzcan las emisiones de $\mathrm{CO}_{2}$ con sanciones fuertes. El desarrollo económico de un país, las relaciones obligatorias y contractuales, no pueden realizarse a costa de destruir el planeta ni de aumentar la contaminación. Deben adelantarse movilizaciones humanas para protestar contra las políticas dañinas para la naturaleza y posibilitar la participación de la sociedad civil gestando una agenda inclusiva en la lucha para controlar el cambio climático, que promueva el diálogo y fomente las políticas para restablecer un modus vivendi y negocial que respete el planeta.

La gravedad del problema pareciera no afectar las relaciones obligatorias ante la frialdad de los juristas. Empero, ello afecta directamente la existencia de todos los sujetos de derecho que sufren las consecuencias del cambio climático y la contaminación rampante por la voracidad de las multinacionales y las mafias de la minería demoledoras de la biosfera, todo secundado por la corruptela e inepcia de las autoridades y de la ciudadanía para tomar medidas en forma geométrica y catastrófica. Hay 
creciente extinción de especies vivientes, del ecosistema, de la flora y de la fauna que supera las tasas naturales de extinción generando notorios efectos nocivos para la supervivencia del propio ser humano.

Ahora sí, las catástrofes naturales y el cambio climático son una amenaza real, son un desafío y comprometen la cadena alimenticia, el ciclo económico, el medio ambiente, la temperatura global, la agricultura, la producción de alimentos y de ciencia y atentan contra los derechos humanos y de ciudadanía mundial. Se demanda un replanteamiento de la cosmovisión jurídica y de la concepción legal en la relación obligatoria, porque desastres naturales y cambio climático afectan gravemente el ejercicio y goce de los derechos de toda índole no solo para un grupo sino, para millones de seres humanos y ponen en juego la supervivencia de la humanidad entera. Al acto o negocio jurídico se deben incorporar cláusulas de garantía contentivas de fuertes sanciones económicas y reparativas que permitan su resiliencia o restablecimiento y, si la convención afecta el medio ambiente, debe ser enjuiciable por nulidad absoluta no saneable. Licencias y concesiones, contratos y convenciones que celebren particulares, Estados con otros Estados o con transnacionales o entre sujetos de derecho de cualquier índole cuando impactan el medio ambiente deben ser judicializados ante tribunales nacionales $\mathrm{y}$, agotadas las vías nacionales, debe apelarse a los controles de convencionalidad ante las cortes internacionales de derechos o tribunales transnacionales por violación de los derechos humanos en el ámbito internacional así el daño o el contrato haya ocurrido o se haya celebrado en el ámbito nacional, puesto que cuanto afecta a una persona en una región directamente incide en los demás habitantes de la tierra, por perjudicar bienes comunes universales que tienen que ver con la supervivencia de todo el género humano.

\section{Inserción del principio de la solidaridad social}

La progresiva crisis de muchos de los fundamentos del Derecho tradicional para resolver los problemas de la ciudadanía en el mundo contemporáneo y la incapacidad del Estado para proteger convenientemente los derechos de las personas - ya sea por causa de la omnipotencia 
del contratante fuerte, por el empoderamiento de las personas jurídicas, por la superioridad de los Estados económicamente boyantes o por el monopolio de las grandes transnacionales- obliga a reformular la interpretación y la aplicación del derecho desde la solidaridad social. Bajo este principio, todo sujeto de derecho o todo grupo tiene la obligación de contribuir al bienestar de sus congéneres, especialmente con respecto a quienes se encuentran en condiciones de debilidad jurídica o material ${ }^{4}$.

No es del todo cierto hoy, bajo los cánones de los códigos de estirpe liberal, que en la contratación haya prevalencia de los principios de igualdad o de la autonomía de la voluntad para obligarse, porque en múltiples contratos una de las partes impone las condiciones a la otra y, en la mayoría de los casos, los contratos son de adhesión. Por ello, se reclama con insistencia la aplicación de los principios de solidaridad y de equidad. El ordenamiento jurídico, entonces, no puede quedar impávido ni estar a la retaguardia para el restablecimiento de los derechos de la parte débil en la relación jurídico-económica, porque los principios tradicionales de igualdad contractual y de autonomía de la voluntad, habiendo sido ayer reglas de oro, hoy resultan la excepción.

El principio de solidaridad procura la subsistencia de la sociedad y de la familia como núcleo y célula fundamental del tejido social, beneficiando a la colectividad en procura de fines comunes. Desde esta perspectiva, la solidaridad es un vínculo, un compromiso perdurable en el tiempo y en el espacio que obliga a cada individuo a responder social y jurídicamente ante la propia sociedad y ante terceros y rectamente a cada uno por el grupo, y al grupo por cada uno. La solidaridad es un principio, una norma y un derecho con esencia ética, que endereza las situaciones jurídicas hacia una relación horizontal de igualdad ${ }^{5}$ y que incorpora a

4 La Corte Constitucional colombiana, para edificar la solidaridad familiar, justifica la preeminencia de este principio con las reglas 5, 13 y 42 de la Carta.

5 La solidaridad social supone la idea de cooperación. En las sociedades modernas, la realización de la igualdad no ha de ser obra sólo de los poderes públicos, sino también de la sociedad, porque todos nos beneficiamos de sus productos. La solidaridad potencia el altruismo limitado de los seres humanos, ello hace que se distinga de los demás valores porque no genera directamente derechos, sino obligaciones que correlativamente dan lugar a derechos. Impulsa el reconocimiento de la realidad del otro y la superación de la dialéctica del odio, del amigo/enemigo, como motor de la política. Es decir, la solidaridad nos incorpora a la idea de que los problemas no son sólo problemas del poder político, sino también de los ciudadanos. La solidaridad social supone "reglas del juego limpio en el mercado" en la aplicación e interpretación de los derechos, 
cada sujeto en el cumplimiento de tareas colectivas internalizando el deber de ayuda y de protección por el otro ${ }^{6}$.

\section{Acceso a la información objetiva, veraz e imparcial como Derecho fundamental}

Usuarios, consumidores y adquirentes de bienes y servicios dentro del ciclo económico, carecen de información suficiente y completa: únicamente reciben la propaganda que a diario bombardea el fabricante, el productor o el distribuidor para doblegar su psiquis, su libertad y su libre decisión. Sobre este aspecto, la Corte Constitucional colombiana ha señalado:

El empresario o productor busca mediante la propaganda anunciar el artículo o servicio informando al público ciertos datos relacionados con la clase de producto, la calidad del mismo, sus ventajas o beneficios, usos, utilidad, etc., y de esta manera influir en la conciencia de las personas a quienes se dirige, para que adquieran el artículo o utilicen el servicio ofrecido y, como lo afirman los especialistas, incrementar de este modo las ventas y obtener mayores ganancias. La publicidad permite que la persona se forme una opinión, y será ella quien, autónoma e independientemente, decida si compra el artículo o utiliza el servicio ofrecido (Corte Constitucional, Sentencia C-524 de 1995).

Por tanto, si la información que se suministra no es completa, veraz y ajustada a la realidad, indiscutidamente debe existir responsabilidad cuando el destinatario sufre perjuicio como usuario, consumidor o adquirente del bien o servicio. No puede el Derecho ignorar que es mediante técnicas agresivas de publicidad como los productores, distribuidores, fabricantes,

promoviendo el proceso de especificación de los derechos de la persona concreta en situación de debilidad. Por ejemplo: los consumidores (López, 2003).

6 Precisamente, la Corte Constitucional colombiana, ha señalado las formas que puede adquirir la solidaridad: "[...] se puede presentar en tres facetas, a saber, (1) como una pauta de comportamiento conforme a la cual deben obrar las personas en determinadas ocasiones; (2) como un criterio de interpretación en el análisis de las acciones u omisiones de los particulares que vulneren o amenacen los derechos fundamentales; (3) como un límite a los derechos propios" (Corte Constitucional, Sentencia T-1096 de 2008). 
banqueros $y$, en general, el contratante fuerte arrebata el consentimiento a la parte débil de la relación jurídica, extremo obligacional, usualmente ignorante del tema y de la información transmitida en torno al producto o servicio en su forma, contenido, garantías legales o contractuales, finalidades, defectos y virtudes, ventajas y desventajas; de manera que el derecho a la información objetiva, veraz e imparcial no puede ser menoscabado, ni mucho menos, desapercibido para resolver el litigio por parte del juez o del árbitro.

\section{Necesidad de restablecer el equilibrio contractual por vía de la intervención del Estado}

Con miras a proteger los intereses individuales y sociales y los de las mayorías que concurren al tráfico jurídico económico diario, el nuevo Derecho Obligacional ha de procurar restablecer el equilibrio contractual, un cometido que únicamente puede obtenerse incentivando políticas de intervención estatal7.

El Código Civil francés ya había limitado el decimonónico principio de la autonomía de la voluntad al establecer en su artículo sexto: "On ne péut déroger, par des conventions particulières, aux lois qui intéressent l'ordre public et les bonnes mours", texto que traduce: "No cabe excluir por acuerdos entre particulares, las leyes que afecten al orden público y a las buenas costumbres" (Código Civil Francés, 2005, p. 4); de tal forma, aunque se respeta, la libertad contractual no puede ser del todo absoluta. El concepto autonomía, recurrentemente utilizado y vital en

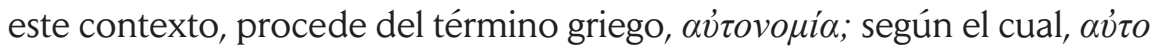
traduce, uno mismo, por sí mismo y vopía: norma, ley. En consecuencia, significa el poder o facultad de darse así mismo las normas o las propias

7 Al respecto, Espin Canovas anota: “En aras de esa función social del Derecho, el Estado de esta época, sin distinción de países ni de ideologías; se ve forzado a invadir el campo de la autonomía privada, ese recinto amurallado en que el ser humano podía atrincherarse en el pasado siglo bajo el signo de la exaltación de los derechos individuales. Y asistimos así, a esa profunda mutación de tantos derechos subjetivos privados, que trasciende a la radical fundamentación de todo el Derecho privado, objetivamente considerado" (1955, p. 9). 
leyes sin estar sometido a ningún poder, de disponer de lo propio, de autorregularse, de ejercer su propia soberanía.

La noción de autonomía de la voluntad históricamente se forjó como expresión del pensamiento liberal de los siglos XVIII y XIX y de la teoría clásica de los derechos naturales del individuo, caracterizada como poder originario y soberano de decidir, de ordenar la propia conducta y de regular por sí mismo sus intereses y relaciones jurídicas y de esta manera se insertó en los códigos civiles de la época. Es un criterio voluntarista, de tal modo que la autonomía de los particulares pende de la propia voluntad, infiriendo que los actos jurídicos son su expresión. En consecuencia, la voluntad aparece como la fuente y la medida de los derechos subjetivos, creadora de la relación jurídica y del vínculo obligacional y, por tanto, del contrato. Esta tesis, esencial para el pensamiento de Grocio, Hobbes, Locke y Rousseau, quienes como ideólogos de la teoría de los derechos naturales e inalienables del individuo, como anteriores al Estado, exaltan la libertad y, como corolario, la autonomía de la voluntad, que se expresó también coetáneamente en la máxima laissez faire, laissez passer, suponiendo que las partes en las relaciones sociojurídicas actúan en pie de igualdad para discutir libremente el contrato.

Pero el concepto de la autonomía de la voluntad entró en crisis y evolucionó al contemporáneo de autonomía privada, negocial, preceptiva o contractual, donde ya no es la simple voluntad o querer, sino el poder o potestad de la persona para autorregularse la facultad que otorga a los individuos el ordenamiento jurídico, incluyendo la propia Constitución, en cuanto señalan los efectos de la manifestación de la voluntad, motivo por el cual puede denominarse también autonomía normativa. De acuerdo con Ferri, se concibe como la potestad normativa concedida por el ordenamiento jurídico a las personas para regular sus propios intereses (1969). En este sentido el artículo 1602 del Código Civil colombiano es la expresión de esta categoría, cuando dispone: "todo contrato legalmente celebrado es una ley para los contratantes, y no puede ser invalidado sino por un consentimiento mutuo o por causas legales".

En el marco de las corrientes alemanas, Savigny (2004) ubica la voluntad como parte del negocio jurídico, conjugando como primer elemento la voluntad del individuo, el elemento interno, su espíritu; el cual se anima y completa con el segundo, consistente en la voluntad objetiva, 
esto es, el ordenamiento jurídico como medio de protección y sujeción de la voluntad particular, de tal forma que esta por sí sola deja de ser plenamente soberana. El acto o negocio jurídico producirá efectos si están previstos en las normas (teoría preceptiva). Por esta razón, la categoría negocio jurídico es el supuesto de hecho previsto en la norma jurídica, $\mathrm{y}$, en consecuencia, su contenido es preceptivo, en cuanto la voluntad ejecuta, materializa o desata los efectos previstos en las normas. Significa lo expresado que la autonomía privada se integra por la concurrencia de la voluntad y del ordenamiento jurídico, es decir, de la conjunción de la atribución legal para crear, modificar o extinguir relaciones obligatorias y de la facultad de la voluntad que usa, goce, dispone, ejerce derechos subjetivos y contrae obligaciones.

En el ámbito del Estado Social de Derecho, el ejercicio de la autonomía negocial o privada, no debe entenderse como mera expresión de la voluntad sujeta al ordenamiento jurídico superior, ajena y aislada de la realidad y de los conflictos cuando contraviene o afecta injustificadamente, y aún dentro del marco legal, los derechos de las partes, de terceros, de la comunidad o del medio ambiente. Debe comprenderse como una categoría que, cuando se despliega como expresión de la libertad negocial, tiene decisivos efectos sociales y políticos que pueden perturbar directa o indirectamente los derechos fundamentales de las otras personas, porque el todo no se puede separar de la parte, caso en el cual se relativiza.

Bajo esta tesitura el negocio jurídico (categoría alemana) o el acto jurídico (de linaje francés), son expresiones normativas sujetas al ordenamiento de mayor jerarquía como la ley, y con rigor a la Constitución $\mathrm{y}$ al bloque de constitucionalidad (el entramado de valores, principios y derechos constitucionales). De tal modo, la autonomía privada expresada en los actos o negocios jurídicos llena los espacios y los poros que deja el ordenamiento. Sin embargo, permanentemente está sujeta a la intervención por parte de la autoridad política o por el juez, cuando en su ejercicio afecta los derechos de la comunidad, los intereses superiores o los derechos constitucionales, con el fin de reconducir la manifestación de la voluntad a los cauces legales o constitucionales, preservando de esta manera la equidad y la justicia como supremos principios. 
En consecuencia, el principio de la autonomía de la voluntad ${ }^{8}$, que luego transitó al de autonomía privada, debe ser reconocido a las personas para regular libremente relaciones jurídicas obligatorias entre sí; en el contexto económico actual donde imperan relaciones desiguales entre las partes contratantes, su alcance debe ser restringido.

En efecto, en una economía de mercado, con cambios intempestivos y acelerados, principios decimonónicos como la autonomía de la voluntad, pacta sunt servanda, en cuanto los contratos celebrados deben ser cumplidos de buena fe; res inter alios acta, tertiis neque nocere neque prodesse potest, según el cual un negocio jurídico celebrado es ley para las partes pero no puede beneficiar o perjudicar a terceros, salvo excepciones legales o de orden público; ex consensu advenit vínculum, traduciendo que del consentimiento proviene la obligación de cumplir con las prestaciones convenidas, entre otros, no pueden ser aplicados en forma automática y acrítica, en condiciones de inequidad rampante entre quienes como contratantes concurren al intercambio comercial y económico, ante el desproporcionado y evidente desequilibrio existente hoy entre las partes contratantes y, además, por la carencia de información y de instrumentos racionales para valorar la publicidad parcial y envolvente que se bombardea diaria y despiadadamente al receptor y destinatario de la misma. Carlos A. Soto sostiene sobre la cuestión:

Así, la doctrina jurídica del siglo Xx consideró necesario imponer severas limitaciones al principio de la autonomía privada con la finalidad de corregir el abuso en la contratación, producto de la desigualdad económica. En esta medida, la autonomía privada ya no impera soberanamente como otrora, pues el Estado interviene en las relaciones contractuales, modificando sus cláusulas (dirigismo contractual y revisión

8 In extenso, se ha expuesto el concepto y mutación de esta categoría. Principio fundamental del derecho privado que surgió política y jurídicamente en la Revolución francesa y filosóficamente en la teoría contractualista, según la cual los particulares en ejercicio de sus libertades y libre determinación someten los efectos de su comportamiento, de sus actos y negocios jurídicos a las autorizaciones legales y hoy a las supralegales y convencionales, así como a las cláusulas derivadas del mutuo acuerdo o del mutuo disenso, siempre y cuando no contravengan disposiciones imperativas de la ley o de la constitución de obligatorio cumplimiento por tratarse de normas de orden público nacional o internacional. "En la esfera de la autonomía privada, para disponer de un interés es necesario ser titular de él, y, por consiguiente, a nadie le es permitido mandar en casa ajena" (Scognamiglio, 1977, p. 27). 
judicial), forzando a veces a celebrarlos a pesar de la voluntad contraria de los contratantes (contratos forzosos, o dispensándolos en otras de ejecutar sus prestaciones) (2003, p. 7).

En suma, el Estado y sus jueces deben partir del hecho de que uno de los contratantes se encuentra en una situación de privilegio y de posición dominante, frente a un usuario o consumidor inexperto y carente de toda la información clara, precisa e imparcial, con respecto a la elaboración, riesgos y efectos dañinos para la salud o para el ambiente de un determinado bien, servicio o producto. En ese panorama, es claro, los principios tradicionales resultan ineficaces e incapaces y deben ceder ante la necesidad de restablecer el equilibrio contractual, motivo por el cual la nueva hermenéutica jurídica debe abstenerse de aplicar aquellos criterios clásicos que defiendan una igualdad abstracta ajena a la realidad, al margen de las nuevas realidades socioeconómicas y jurídicas actuales, porque de otro modo se esquilman los derechos de la parte débil, ignorante o desinformada.

\section{Amplia protección de los derechos de usuarios y consumidores}

Debe abogarse por un ejercicio fuerte de controles contractuales para obtener un equilibrio en favor de quienes se encuentran en debilidad en cualquier hipótesis de asimetría contractual, otorgando una enérgica tutela al consumidor, más allá del sistema liberal decimonónico autorizado en los códigos vigentes, haciendo énfasis, ante todo, en las ventas y garantías de los bienes de consumo.

Con todo, países como Colombia han elaborado un Estatuto del Consumidor Autónomo', del mismo modo que algunos europeos; algunos otros, como Alemania, han introducido este derecho al interior del código civil $^{10} \mathrm{o}$ incluso tiene consagración constitucional como en el

9 En Argentina, el Estatuto del Consumidor es la Ley 24240; en Chile, la Ley 19496; en México, la Ley General de Protección al Consumidor de 1976, la cual crea la Procuraduría Federal del Consumidor (PROFECO).

10 En la Sección Primera del Libro I del Código Civil Alemán (BGB), referente a las personas, 
caso de España ${ }^{11}$. A juicio de algunos críticos, esta inserción resulta confusa. En el caso de Alemania porque genera problemas de interpretación sistemática frente a la historia del mismo BGB y, en el caso de España, por su consagración expresa como principio rector de la política social y económica cuando, en realidad, su naturaleza jurídica corresponde a un genuino derecho. No obstante, pese a estas críticas, lo cierto es que la inclusión de los derechos del consumidor al interior de las codificaciones modernas es presupuesto necesario e imprescindible de la contratación actual para alcanzar la igualdad dentro del marco de una autonomía privada "limitada", por los efectos inmediatos y relevantes que representa para la totalidad de las personas en todos los rincones del orbe en su vida cotidiana por su condición de consumidores efectivos o potenciales, minuto a minuto, día a día ${ }^{12}$.

En Colombia, el camino para abonar la protección al derecho del consumidor se halla en el artículo 78 de la Carta Política de 1991. El punto en principio y en forma sistemática fue abordado en el Decreto 3466 de 1982; hoy, en el actual Estatuto del Consumidor, la Ley 1480 del 2011. Esta última disposición se ocupa de las transacciones del comercio electrónico, los métodos de venta no tradicionales o a distancia, la protección ante las cláusulas abusivas en los contratos de adhesión, la obligación de garantía en materia de consumo, la calidad e idoneidad de los productos, las obligaciones de seguridad en la materia, las garantías

define al consumidor como: "toda persona natural que celebra un negocio jurídico con una finalidad que no guarda relación con su actividad profesional empresarial o autónoma" (2008, p. 36).

11 De acuerdo con el artículo 51 de la Constitución Política española: "1. Los poderes públicos garantizarán la defensa de los consumidores y usuarios, protegiendo, mediante procedimientos eficaces, la seguridad, la salud y los legítimos intereses económicos de los mismos" (Constitución Política, año). Así mismo, los derechos del consumidor se encuentran regulados en varios instrumentos de la legislación española: la Ley de Condiciones Generales de Contratación (Real Decreto Legislativo 1/2007) y la Ley de Crédito al Consumo (Ley 16/2011).

12 Al respecto, López Camargo sostiene: "Hoy día, la necesidad de proteger integralmente al consumidor, potencial o actual, actúa como idea motriz de una serie de acciones de política legislativa, por lo que muchos países han consagrado en sus constituciones, preceptos, valores y principios que dan sustento a la protección de los consumidores, convirtiendo en una realidad jurídica lo que ya era una realidad socio-económica. Se consagran nuevos valores superiores del ordenamiento jurídico constitucional, informadores y ordenadores del sistema económico establecido en la Constitución económica: el mercado, la competencia y la competitividad, la productividad empresarial, el valor de adecuación socioeconómica de la actividad empresarial, el valor de la democracia económica y la participación, la solidaridad social, la igualdad material y la justicia social" (2003, p. 3). 
de cumplimiento de obligaciones derivadas de la prestación del servicio de parqueadero, la responsabilidad por daños por producto defectuoso, la información y la publicidad en los bienes y servicios ofertados al consumidor, así como los contratos de adquisición de bienes y prestación de servicios en los cuales el productor o proveedor otorgue financiación, etc.

El constitucionalismo colombiano en el año 1991 preocupado por tan importante realidad contemporánea, insertó en el capítulo tercero de la Constitución, referente a los derechos colectivos y del medio ambiente, el artículo 78 encaminado a proteger los derechos al consumidor, señalando:

La ley regulará el control de calidad de bienes y servicios ofrecidos y prestados a la comunidad, así como la información que debe suministrarse al público en su comercialización.

Serán responsables, de acuerdo con la ley, quienes en la producción y en la comercialización de bienes y servicios, atenten contra la salud, la seguridad y el adecuado aprovisionamiento a consumidores y usuarios.

El Estado garantizará la participación de las organizaciones de consumidores y usuarios en el estudio de las disposiciones que les conciernen. Para gozar de este derecho las organizaciones deben ser representativas y observar procedimientos democráticos internos (Constitución Política, 1991).

El precepto consigna los principios esenciales que guían la protección de los derechos del consumidor otorgando un papel activo e interventor al Estado de modo que pueda ejercer las facultades de inspección y vigilancia en la calidad de los bienes y servicios prestados para avanzar desde la neutralidad tradicional de los poderes públicos a la protección reforzada, interviniendo la autonomía de la voluntad ${ }^{13}$.

De esta manera por vía constitucional se modifican principios tradicionales relacionados con la autonomía de la voluntad privada, los efectos relativos y la interpretación contractual, el derecho de daños, las acciones

13 En el marco de estos principios no se trata de apostar por un totalitarismo de Estado, porque el principio de autonomía privada es esencial en el derecho obligacional y columna vertebral del mismo, sino de buscar un control al principio de autodeterminación cuando este se extralimita y se torna arbitrario, de tal forma que no ponga en peligro la libertad contractual y el desarrollo económico con equidad y justicia, equilibrio entre poderes públicos y autonomía privada, sin socavar los derechos fundamentales de la parte débil en la relación obligatoria. 
para la protección de los usuarios y consumidores. Es una concepción consustancial a la categoría de Estados Sociales de Derecho, superando la primigenia concepción liberal que se fundó en una relación de igualdad formal y ficticia y de absoluta libertad jurídica y económica de negociación entre consumidor y productor. Una Constitución democrática es eficaz si aboga por el resguardo de los derechos de los consumidores $y$, en general, de los sectores más débiles en las relaciones obligatorias, otorgando una protección reforzada, entendida como discriminación positiva en cuanto impone tratar de manera distinta a personas diferentes, en pos de obtener las condiciones para que haya "[...] igualdad [...] real y efectiva [...]" (Constitución Política, 1991). El derecho colombiano desarrolla esos principios en la Ley 1480 de 2011 en forma prolija y tuitiva.

Cobra sentido una interpretación pro consumator con relación a las leyes del contrato al fijar normas especiales que establecen la responsabilidad de productores, limitan la imposición de cláusulas abusivas, regulan la publicidad y otros derechos y deberes de productores y consumidores. Siguiendo esos postulados, con tino, la Sala de Casación Civil de la Corte Suprema de Justicia de Colombia, en la sentencia del 30 de abril de 2009 sostiene: "[...] la protección del consumidor no solo encuentra respaldo en esa preceptiva constitucional, sino también en el Artículo 13 de dicha Carta, en cuanto establece que «el Estado promoverá las condiciones para que la igualdad sea real y efectiva y adoptará medidas a favor de grupos discriminados o marginados»". (Corte Suprema de Justicia. Sala Civil. Expediente No. 258993193992199900629 01, 2009). En las relaciones obligatorias que surgen con ocasión del derecho al consumo, es indudable que productor (fabricante, empresario, distribuidor) y consumidor (destinatario de los bienes y servicios), se hallan en posiciones diferentes porque este último es la parte débil mientras que aquél es la fuerte en la relación económica de consumo (Sánchez, 1997), resultando necesaria la discriminación positiva.

La Sala Civil de la misma Corte, haciendo un análisis de este nuevo derecho, con claridad adoctrinó:

Desde esa perspectiva, la relación de consumo constituye una particular categoría que surge entre quienes se dedican profesionalmente a elaborar o proveer bienes o prestar servicios con quien los adquiere 
para consumirlos; y es precisamente el consumidor, quien, por encontrarse en condiciones de vulnerabilidad económica y de desequilibrio, es destinatario de una especial protección normativa; por supuesto que la profesionalidad del productor, que lo hace experto en las materias técnicas y científicas en torno de las cuales realiza su labor, su sólida capacidad económica, su vocación para contratar masivamente, las modalidades de contratación a las que acude, entre muchas otras peculiaridades, lo sitúan en un plano de innegable ventaja negocial que reclama la intervención de legisladores y jueces con miras a restablecer el equilibrio perdido (Corte Suprema de Justicia. Sala Civil, Expediente No. 258993193992199900629 01, 2009)14.

Como secuela, ha de darse preeminencia al Derecho del consumidor en los ámbitos nacionales e internacionales. Todos somos consumidores, porque participamos a diario y sin distingos en actos de consumo de alimentos, fármacos, ropa o servicios, forjándose relaciones directas e indirectas con distribuidores, fabricantes y proveedores tanto de bienes como de servicios y, como dentro de esa nube negocial y de transacciones se halla solo y desamparado el usuario o el consumidor, se impone el principio del favor débilis a fin de garantizar el orden público económico nacional e internacional justo ${ }^{15}$. Los consumidores demandan protección eficaz, representación y acceso a la justicia ante las autoridades administrativas y judiciales, y frente a los empresarios. Sus derechos son de interés colectivo o difuso y con carácter permanente por su clara dimensión social, por cuanto toda determinación afecta a la comunidad o al conglomerado social, así unos consumidores sufran o se beneficien más que otros, no se

14 Años antes, en la misma Corte, la sentencia del tres de mayo de 2005, en el expediente 50001-3103-001-1999-04421-01, había definido el concepto de consumidor, como el sujeto de derecho que "[...] contextualmente, aspire a la satisfacción de una necesidad propia, privada, familiar, doméstica o empresarial -en tanto no esté ligada intrínsecamente a su actividad económica propiamente dicha, aunque pueda estar vinculada, de algún modo, a su objeto social-, que es lo que constituye el rasgo característico de una verdadera relación de consumo".

15 Un sector de la doctrina, considera que no siempre el consumidor es la parte débil en la relación contractual, con lo cual se rechaza la tesis según la cual existe una desigualdad de poder económico existente entre los proveedores de bienes y servicios y los consumidores o destinatarios finales. Soto, refiriendo la doctrina argentina y peruana anota: "para el argentino Farina y el peruano De la Puente, no siempre el consumidor o usuario es parte débil en los contratos. En igual sentido se han orientado ambos derechos. Sin embargo, INDECOPI, en el caso peruano, ha optado por un camino distinto: el tema de la información asimétrica" (Soto, 1997, p. 229). 
trata de intereses meramente particulares, sino comunitarios y masivos. Con mayor razón, urge la protección porque el juego de intereses no es pacífico, puesto que frecuentemente se encuentran en continuo enfrentamiento los objetivos del fabricante, del productor, del distribuidor o empresario con los del consumidor, y los primeros procurarán mayor utilidad con menor inversión.

Ante la masificación de la economía, la comunidad internacional inició un programa de protección de los consumidores mediante variados instrumentos normativos; así por ejemplo, el Tratado de Roma de 1957, incorporó preceptos de protección para el gran nuevo sujeto del derecho "el consumidor", en los artículos 39, 85 y 86. La nueva entidad socioeconómica europea, en 1972 adoptó la Carta Europea de Protección al Consumidor. La Resolución 39/248 del nueve de abril de 1985 de la Asamblea General de las Naciones Unidas fijó criterios para su protección, en la siguiente forma:

Artículo 17. Los gobiernos deben elaborar, reforzar o mantener, según proceda, medidas relativas al control de las prácticas comerciales restrictivas y otras de tipo abusivo que puedan perjudicar a los consumidores, así como medios para hacer efectivas esas medidas. Al respecto, los gobiernos deben guiarse por su adhesión al Conjunto de principios y normas equitativos convenidos multilateralmente para el control de las prácticas comerciales restrictivas, aprobado por la Asamblea General en su resolución 35/63, de 5 de diciembre de 1980 (Resolución 39/248, Asamblea General de las Nacional Unidas, 1985).

Y en su artículo 21, dispuso:

Los consumidores deben gozar de protección contra abusos contractuales como el uso de contratos uniformes que favorecen a una de las partes, la no inclusión de derechos fundamentales en los contratos y la imposición de condiciones excesivamente estrictas para la concesión de créditos por parte de los vendedores (Resolución 39/248, Asamblea General de las Nacional Unidas, 1985).

La Corte Constitucional colombiana en una apretada síntesis, caracteriza el derecho del consumidor de la siguiente manera: 
Se pueden afirmar [...], que se trata de un conjunto de normas encaminado a subsanar las asimetrías evidenciadas en el mercado y derivadas, entre otras circunstancias, de las diferencias en materia de capacidad económica y de la posesión de información cualificada. También se puede sostener que se trata de un derecho eminentemente dinámico, condicionado a las variaciones de la situación de consumidor y productor en el escenario cambiante del mercado. Igualmente, se puede advertir que la lectura de los contratos surgidos en el mercado entre consumidores y productores, debe hacerse teniendo como norte los principios constitucionales de protección al consumidor (Corte Constitucional. Sentencia C-313, 2013) ${ }^{16}$.

En la cuestión, como principios medulares deben imponerse la responsabilidad solidaria de fabricantes, distribuidores e importadores, en general, de todos los entes y personas que intervienen en la cadena económica frente al usuario o consumidor; la invalidez de pleno derecho de la cláusulas exonerativas de responsabilidad para los productores, importadores, fabricantes y distribuidores; prescindencia de la demostración de la culpa tratándose de la responsabilidad por infracción a los derechos al consumidor; la creación de un fondo de garantías a cargo de los fabricantes, productores y distribuidores a favor de los consumidores para reparar los perjuicios que puedan causar a estos, etc.

Asimismo, para una efectiva protección del consumidor, se hace necesario imponer el principio de responsabilidad objetiva en los supuestos de daños causados por riesgos y vicios de las cosas. Tratándose de actividades peligrosas o riesgosas, realmente debe indemnizarse sin consideración a la culpa, por quien se beneficia con la actividad que es fuente del riesgo. El interés central ha de ser, como se reitera, la víctima ante el daño causado y no tanto la situación del victimario, a fin de proteger a aquélla en forma conveniente de los desafueros, de la omnipotencia o del abuso de poder del extremo obligacional o contractual dominante. En este contexto, el empresario o quién se beneficia de la actividad debe

16 En sentido análogo, en la Sala Civil de la Corte Suprema, en sede de casación, es prolija en el punto la sentencia del 30 de abril de 2009, expediente 25899319399219990062901 , con ponencia del Dr. Pedro Octavio Munar Cadena. 
soportar el riesgo, conforme al principio ubi emolumentum ibi onus (quien se beneficia de una actividad debe soportar los riegos que origina).

De este modo, ha de proscribirse el ejercicio ilimitado de atributos como dique de contención contra el abuso del derecho o de las situaciones jurídicas arbitrarias y desmedidas con respecto a derechos individuales o colectivos. El interés público ha de ser prevalente en el ámbito del Derecho Privado para reprimir y restringir el uso de cláusulas de irresponsabilidad o imposiciones contractuales que contengan abuso del derecho o de posición dominante frente al contratante débil porque no todas las personas se encuentran en pie de igualdad para contratar. Tampoco el progreso económico puede fundarse en la tolerancia de los otros sujetos de derecho ante el daño, mucho menos en la asunción de riesgos por parte de quien no genera la actividad peligrosa. El destinatario de un contrato, el usuario, el consumidor, deben tener completa y suficiente información del potencial dañino de un producto o de una actividad o de los efectos jurídico-económicos de la cantidad de contratos que irrestrictamente debe aceptar como extremo débil en el marco obligacional. Ello obliga a efectuar una interpretación contra proferentem, integral y auténtica, o a la luz del principio interpretatio contra stipulatorem, que obliga a realizar exégesis de los negocios jurídicos en contra de la parte que redactó la cláusula ambigua o contradictoria, o con respecto a quien pretende oscuridad. Del mismo modo, debe potenciarse la hermenéutica pro consumatore para los contratos de adhesión como los de seguros, al tener estipulaciones predispuestas, esto es, juzgando en pro del derecho del consumidor; modalidades contractuales que suelen ser carentes de la negociación y de la discusión de los contenidos y por tanto, ausentes del todo de la verdadera autonomía de la voluntad contractual.

\section{Una nueva concepción de la responsabilidad como Derecho de Daños}

Independientemente del tipo de culpa en la responsabilidad o de la existencia o no de ella, debe indemnizarse por el daño causado, teniendo como criterio, no tanto la conducta antijurídica, sino el daño antijurídico; por ello, es preferible hablar de derecho de daños, en lugar de responsabilidad. Se trata de un cambio copernicano en el análisis de los 
problemas y de las relaciones obligacionales cotidianas, porque el centro de protección y de atención es ahora la víctima o el dañado, el usuario del servicio o el consumidor. Sobre este punto, José Luis Concepción en su obra El derecho de daños, sostiene:

El derecho de daños o de la responsabilidad Civil ha seguido una constante evolución a lo largo de la historia. Se estructuró tradicionalmente según criterios marcadamente individualistas, a partir de un juicio de reproche del comportamiento del agente y del principio de que la culpa debe perjudicar a su autor - sua cuique culpa nocet- y hoy camina hacia soluciones que prescinden, en mayor o menor grado, de ese componente subjetivo, ante la exigencia social de dar satisfacción a la víctima (Concepción, 2009, p. 11).

Lo anterior impone la necesidad de incentivar la prevención del daño en materia de responsabilidad antes que la reparación del mismo. En efecto, hoy debe potenciarse el restablecimiento del equilibrio y de la justicia, como propósito central del nuevo Derecho a través de una educación cultural y política que haga énfasis en prevenir los comportamientos antijurídicos a través del respeto a los derechos del otro, del cumplimiento de los deberes jurídicos y de la tolerancia como instrumentos para garantizar la convivencia social. Soluciones de esta naturaleza resultan más benéficas que los controles y resarcimientos a posteriori, porque el inmenso arsenal de recursos puede dedicarse para el desarrollo de actividades encaminadas a proteger plena y dignamente las necesidades de los ciudadanos de todo el orbe. Ello apareja estudiar, de la misma manera, mecanismos para prohibir ejercer actividades riesgosas in extremis.

\section{Buena fe, deberes primarios y secundarios de conducta y teoría del acto propio}

\subsection{Importancia}

Es necesario preservar e incentivar la buena fe, bonae fidei, principio que recorre el ordenamiento jurídico en su integridad, y, por supuesto, el derecho de las obligaciones en sus diferentes manifestaciones, porque forma parte de su propia médula, ya que constituye un elemento 
estructural fundante, con fuerza y jerarquía superior para la totalidad de los actos y relaciones jurídicas, incluyendo el Derecho de Daños, al punto que los ordenamientos contemporáneos le han dado carta de ciudadanía en los propios textos constitucionales. Hoy es herramienta necesaria en toda clase de contratos para prevenir cláusulas abusivas e inequidades contractuales que contrarien los fines legales o constitucionales: es instrumental para luchar contra la desnaturalización de los derechos y las obligaciones de las partes en procura de un trato equitativo.

\subsection{La buena fe. Sus diversas manifestaciones en el derecho obligacional}

En la evolución de esta categoría podemos encontrar hoy diversas modalidades y alcances en el tratamiento de la buena fe, pero se destacan, como dos grandes grupos, la buena fe subjetiva y la buena fe objetiva para comprender la gran incidencia de este principio en el derecho moderno.

\subsubsection{Buena fe subjetiva}

La buena fe subjetiva es la creencia, la convicción o conciencia recta de estar obrando con lealtad conforme a Derecho. Es la sola conciencia interna o psicológica de estar actuando honesta, leal y correctamente, sin que se esté incurriendo en error o sin perjuicio de estar fundada la persona en un equívoco. Es la buena fe ligada con la ignorancia que justifica el error de hecho, no el de derecho. Es mera conciencia porque, al margen de la voluntad, cree que determinadas circunstancias fácticas sean reales o verdaderas, así no lo sean, de tal forma que no exige el cumplimiento de cierta conducta. Esta es la modalidad que se presenta en la posesión, tal cual lo enseña el art. 768 del Código Civil colombiano:

La buena fe es la conciencia de haberse adquirido el dominio de la cosa por medios legítimos exentos de fraudes y de todo otro vicio.

Así, en los títulos traslaticios de dominio, la buena fe supone la persuasión de haberse recibido la cosa de quien tenía la facultad de enajenarla y de no haber habido fraude ni otro vicio en el acto o contrato.

Un justo error en materia de hecho, no se opone a la buena fe. 
Pero el error, en materia de derecho, constituye una presunción de mala fe, que no admite prueba en contrario (2014).

Esta modalidad puede ser simple o calificada. La buena fe simple es la conciencia de obrar con apego al ordenamiento jurídico por los medios previstos legalmente sin que medie fraude $u$ otro vicio, como la requerida para la posesión en los términos del art. 768 pretranscrito. El comportamiento del sujeto puede ser antijurídico, al apuntalarse muchas veces en el error o en la ignorancia; sin embargo, el ordenamiento lo ampara ante la creencia, o situación subjetiva especial como se encuentra el sujeto de derecho al estar plenamente convencido que actúa correctamente. Otro ejemplo se halla en el art. 834 del Código de Comercio de Colombia, en relación con el mandatario, eventos todos ellos, en los cuales no se demanda una conducta activa de parte del sujeto de derecho. En efecto, señala el texto en cuestión:

[...] en los casos en que la ley prevea un estado de buena fe, de conocimiento o de ignorancia de determinados hechos, deberá tenerse en cuenta la persona del representante, salvo que se trate de circunstancias atinentes al representado. En ningún caso el representado de mala fe podrá ampararse en la buena fe o en la ignorancia del representante (Código de Comercio, 2014, p. 338).

Esta clase de buena fe, como se infiere, no demanda un elemento objetivo; ni la diligencia en quien alega la buena fe calificada, como a renglón seguido se explica. La buena fe cualificada, creadora de derecho, exenta de culpa, es la misma buena fe simple pero acompañada de una conducta objetiva o externa que ofrece certeza jurídica, así sea aparente, porque se funda en la creencia invencible de que no se está incurriendo en culpa o fraude; no obstante, esta acompañada de un comportamiento diligente $y$, por estas razones, también es conocida como la teoría de apariencia de derechos, por virtud de la cual lo irreal se transforma en real, simbólicamente, generando efectos jurídicos ante los asociados, pero merced a la ejecución de actos positivos. Por lo tanto, concurren para la existencia de la misma, dos elementos: 1) el subjetivo, que demanda la buena fe simple, como conciencia de que se obra con lealtad y 2) el 
elemento objetivo, consistente en la ejecución de un comportamiento activo por medio de investigaciones o exámenes o actos con propósitos de llegar a la certeza de que se actúa conforme a derecho, consolidando por este camino el elemento subjetivo o creencia interna frente al interés o derecho que se pretende.

Esta modalidad va más allá de la buena fe simple, puesto que debe acompañarse de actividades que la transformen y permitan atribuirle el predicado de calificada, porque la persona debe cerciorarse de que su comportamiento corresponde a la verdad y se ajusta al ordenamiento; de ahí que, por esa otra circunstancia, sea fuente creadora de derecho así este edificada en el error o en la apariencia, motivo por el cual, se itera, es el fundamento del principio error communis facit ius.

En el punto, expresa la Corte Constitucional colombiana:

Tal máxima indica que si alguien en la adquisición de un derecho o de una situación comete un error o equivocación creyendo adquirir un derecho o colocarse en una situación jurídica protegida por la ley, resulta que tal derecho o situación no existen por ser meramente aparentes normalmente y de acuerdo con lo que se dijo al exponer el concepto de la buena fe simple, tal derecho no resultará adquirido. Pero si el error o equivocación es de tal naturaleza que cualquier persona prudente y diligente también lo hubiera cometido, por tratarse de un derecho o situación aparentes, pero en donde es imposible descubrir la falsedad o no existencia, nos encontramos forzosamente, ante la llamada buena fe cualificada o buena fe exenta de toda culpa (Corte Constitucional, Sentencia C-131, 2004) ${ }^{17}$.

Un texto del derecho colombiano propio para entenderla se halla en el art. 1069 del Código Civil al referirse a la inhabilidad oculta o putativa de un testigo testamentario:

Si alguna de las causas de inhabilidad, expresadas en el artículo precedente, no se manifestare en el aspecto o comportación de un testigo, y se ignorare generalmente en el lugar donde el testamento se otorga, fundándose la opinión contraria en hechos positivos y públicos, no se invalidará el testamento por la inhabilidad real del testigo. Pero

17 En igual sentido, ver las sentencias C-1007/02, C-740/03 y C-820/12 
la habilidad putativa no podrá servir sino a uno solo de los testigos (Código Civil, 2014).

En este caso, la teoría del error común otorga validez al negocio jurídico testamentario, como en otros, por la simple apariencia de legalidad o de verdad, teniendo en cuenta que aún las personas más diligentes o en forma concurrente prudentes habrían incurrido en el mismo error. Claro, en estas hipótesis, el error debe ser: 1) error generalizado o colectivo $\mathrm{y}$, además 2) invencible. O sea que hasta los hombres más prudentes y avezados no lo habrían cometido. Al mediar esas circunstancias fácticas con carácter invencible, se reconoce la buena fe exenta de culpa, sin que se pueda invalidar el acto jurídico.

La Corte Constitucional colombiana en sentencia C-1007 de 2002, reiterada en la C-740 de 2003, al analizar la buena fe exenta se fija algunos criterios para su configuración:

[...] además de la buena fe simple, existe una buena fe con efectos superiores y por ello denominada cualificada, creadora de derecho o exenta de culpa. Esta buena fe cualificada, tiene la virtud de crear una realidad jurídica o dar por existente un derecho o situación que realmente no existía.

La buena fe creadora o buena fe cualificada, interpreta adecuadamente una máxima legada por el antiguo derecho al moderno: "Error communis facit jus", y que ha sido desarrollada en nuestro país por la doctrina desde hace más de cuarenta años, precisando que "Tal máxima indica que si alguien en la adquisición de un derecho o de una situación comete un error o equivocación, y creyendo adquirir un derecho o colocarse en una situación jurídica protegida por la ley, resulta que tal derecho o situación no existen por ser meramente aparentes, normalmente y de acuerdo con lo que se dijo al exponer el concepto de la buena fe simple, tal derecho no resultará adquirido. Pero si el error o equivocación es de tal naturaleza que cualquier persona prudente y diligente también lo hubiera cometido, por tratarse de un derecho o situación aparentes, pero en donde es imposible descubrir la falsedad o no existencia, nos encontramos forzosamente ante la llamada buena fe cualificada o buena fe exenta de toda culpa.

El derecho antiguo al decir que un error común creaba derecho, pretendió gobernar con otro criterio la buena fe exenta de culpa. Para 
ello se llegó al extremo de expropiar el derecho al titular verdadero para adjudicarlo a quien había obrado con una fe exenta de culpa, vale decir, convirtió algo aparente, en realidad, es decir, el propio orden jurídico creaba por sus propias energías el derecho o situación que realmente no existía (Corte Suprema de Justicia, Sentencia del 23 de junio de 1958).

Entonces se concluye que, a diferencia de la buena fe simple que exige solo una conciencia recta y honesta, la buena fe cualificada o creadora de derecho exige dos elementos a saber: uno subjetivo y otro objetivo. El primero hace referencia a la conciencia de obrar con lealtad, y el segundo exige tener la seguridad de que el tradente es realmente el propietario, lo cual exige averiguaciones adicionales que comprueben tal situación. Es así que, la buena fe simple exige solo conciencia, mientras que la buena fe cualificada exige conciencia y certeza (Corte Constitucional, Sentencia C-1007 de 2002).

En consecuencia, a la mera conciencia se une la voluntad con la ejecución de un comportamiento diligente en pro de obtener por parte del sujeto jurídico el reconocimiento del derecho, en una situación fáctica que realmente es aparente (legitima la apariencia de verdad), pero protegida por ley, por cuanto cualquier otra persona en circunstancias análogas incurriría en el mismo escenario en ese yerro, motivo por el cual, la ley preserva el derecho de esa persona con apoyo en aquélla máxima ${ }^{18}$.

18 La Corte Suprema de Justicia colombiana en la Sala de Casación Civil, en la sentencia del 20 de mayo de 1936, con ponencia del Mg. Eduardo Zuleta Ángel, analizó la aplicación de la buena fe exenta de culpa en relación con los textos 149, 150, 947, 1547, 1548, 1933, 1634, 1766, 1940, 1944, 2140 y 2199 del Código Civil, en relación con los terceros, señalando que "en todas las hipótesis [...], los terceros quedan protegidos contra las consecuencias de actos jurídicos que no estuvieren en capacidad de conocer. En esta circunstancia -la de que tales terceros no pudieron conocer dichos actos jurídicos - funda el legislador la limitación de los naturales efectos de esos actos. [...] En una y otra hipótesis, [...] la ley consagra, en favor de los terceros de buena fe, el triunfo de la apariencia que los condujo a un error excusable. [...] El legislador colombiano [...] para proteger a terceros de buena fe, le reconoce efectos jurídicos trascendentales a una apariencia de derecho de la cual se ha derivado un error invencible, y hace ceder ante ella la realidad jurídica. En otros términos: cada uno de esos textos consagra una medida de protección en favor del tercero de buena fe que incurrió en un error invencible, y que, como consecuencia de éste, se vería expuesto a que se alegaran contra él las deducciones lógicas implacables de la verdad jurídica que ignoró, si la ley no le hubiera atribuido en todos esos casos a la buena fe exenta de culpa una función creadora de derecho. [...] Lo expuesto en los párrafos anteriores sobre las concepciones doctrinarias y jurisprudenciales concernientes a la buena fe y al error común [...] son consecuencias formuladas por el propio legislador -para hipótesis que él pudo y estimó necesario prever y resolver concretamente- del principio general y superior de derecho consignado en la máxima error communis facit jus, de tan perfecta aplicabilidad dentro del orden jurídico positivo colombiano como dentro del orden jurídico positivo francés, y que 


\subsubsection{Buena fe objetiva}

La buena fe objetiva es la que impone el ordenamiento como deber jurídico de comportamiento y se torna en una regla orientadora para actuar proba y responsablemente en forma real conforme al derecho y no como mera conciencia o creencia. Por este motivo, conlleva por parte de los sujetos ligados por el vínculo obligacional (prenegocial, negocial o postnegocial) la ejecución de verdaderos deberes de conducta mediante actos concretos y procederes, encaminados a ejecutar y cumplir realmente y de buena fe la prestación comprometida. Se trata del sujeto de derecho que actúa como un bonus vir (hombre honesto y correcto), tal como se infiere en el ordenamiento colombiano del artículo 1603 del Código Civil, según el cual "los contratos deben ejecutarse de buena $\mathrm{fe}$, y por consiguiente obligan no solo a lo que en ellos se expresa, sino a todas las cosas que emanan precisamente de la naturaleza de la obligación o que por ley pertenecen a ella" (Código Civil, 2014). Esta bona fides puede ser de naturaleza activa o pasiva.

La buena fe objetiva de carácter activo implica que el sujeto interviniente en la relación obligatoria o contractual ejecute los deberes u obligaciones de conducta impuestos por el ordenamiento o por el contrato con probidad, honestidad y buena fe cumpliendo sus deberes jurídicos.

La buena fe objetiva de carácter pasivo, por otro lado, significa que esa misma parte en el vínculo obligacional tiene el derecho para esperar, confiar y obtener que el otro vinculado en el nexo obligacional actúe conforme a la buena fe, y cumpla correlativamente sus deberes de conducta obrando con lealtad, rectitud, es decir, ajustado a la buena fe objetiva, y del mismo modo, los terceros que de una u otra manera ingresen en el complejo mundo de las relaciones obligatorias interpersonales.

Se plantea esta conceptualización siguiendo la doctrina de la Corte Suprema de Justicia de Colombia en algunas de sus sentencias, como la del 9 de agosto de 2000 cuando, refiriéndose al contenido del artículo 863 del Código de Comercio: “[...] las partes deberán proceder de buena fe exenta de culpa en el período pre contractual, so pena de indemnizar los perjuicios que se causen" (Código de Comercio, 2014) y sostuvo:

a su turno no es otra cosa que la explicación y reglamentación técnica de algunos de los más trascendentales efectos de la función creadora de la buena fe". 
[...] tratándose de relaciones patrimoniales, la buena fe se concreta, no solo en la convicción interna de encontrarse la persona en una situación jurídica regular, aun cuando a la postre, así no acontezca como en la posesión, sino, como un criterio de hermenéutica de los vínculos contractuales, amén que constituye un paradigma de conducta relativo a la forma como deben formalizarse y cumplirse las obligaciones. (Corte Suprema de Justicia, Sentencia de 9 de agosto de 2000).

\subsection{La buena fe y los deberes primarios y secundarios en el derecho obligacional}

Sobre los deberes primarios y secundarios, la postura de la teoría jurídica neopositivista entiende que la norma jurídica contiene dos partes: la conducta o el hecho y la consecuencia jurídica o sanción, esta última tocante con el deber u obligación reflejada en una acción u omisión. Ya Austin (2010) había sentado la necesidad de diferenciar entre deberes primarios y deberes secundarios, cuestión que en realidad, para los normativistas entraña una distinción entre mandatos primarios y mandatos secundarios, porque deber y mandato son correlativos.

En este contexto, los deberes primarios son los mismos mandatos primarios, plasmados en reglas para prevenir los actos antijurídicos, que expresan la conducta deseada por el legislador, de modo que la norma entraña el deber de evitar el acto antijurídico, a tal punto que, si no existieran mandatos jurídicos no existirían deberes jurídicos. En consecuencia, la norma jurídica primaria implica un derecho subjetivo o deber primario; de esta manera, en el ejemplo, todos los seres humanos tenemos derecho a la vida, se está imponiendo el deber de respetar la vida. La norma secundaria es la que contiene la sanción a cumplir cuando no se honre o cumpla la norma primaria, como cuando se afirma, quien irrespete la vida incurrirá en una sanción equivalente a tantos años de arresto ${ }^{19}$.

En el Derecho alemán a partir del Código Civil de 1900, Burgerliches Gesetzbuch (BGB), cuando entró en vigencia, al teorizar las obligaciones como las Schuldverhältnisse o relaciones obligatorias, el deber primario

19 Ahora, en Kelsen, la norma primaria es la que contiene la sanción, mientras que la secundaria se refiere al deber jurídico derivado de la primaria. 
del deudor consiste en cumplir la prestación in natura, según lo previsto en la ley o lo acordado en el contrato, es decir, la pretensión de cumplimiento; mientras el deber secundario se encamina a la indemnización de los daños y perjuicios. Este criterio lo conservó la reforma aprobada en enero del 2002, conocida como Ley de Modernización del Derecho de Obligaciones, acogiendo la teoría de los deberes de protección, cuya infracción es materia de resarcimiento. Por tal razón, el parágrafo primero del artículo 280 del BGB, dispone que "si el deudor viola un deber de la relación obligatoria, el acreedor puede exigir resarcimiento del daño que de ello resulta" (BGB, 2008, p. 84), tanto por los deberes principales de prestación y de cumplimiento (positivos), como de los complementarios de prestación y los autónomos de protección, incluyendo los precontractuales o por culpa in contrahendo.

El principio general de la buena fe (bona fides), tanto en el sentido objetivo (significando exigencia de un comportamiento leal) como en el subjetivo (entendido como creencia o aspecto interno), se destella en la actuación diaria y en la ejecución de obligaciones y contratos por medio de las reglas o deberes primarios y secundarios, por cuanto la relación obligacional es compleja y multiforme, no simplemente lineal.

Los primarios corresponden a los deberes tipificados en la ley y en los contratos, los cuales son de expresa naturaleza prestacional, como por ejemplo en el caso de la compraventa, la obligación de la transmisión de la cosa, el pago del precio, y el saneamiento por vicios; en el caso del arrendamiento, la entrega a título de tenencia de la cosa y el precio o canon, etc.

Los segundos, denominados también conexos, secundarios de conducta, colaterales, complementarios o contiguos, tales como los de información, protección o seguridad, consejo, fidelidad o secreto, entre los más relevantes, se caracterizan por estar referidos al deber general de actuar de buena fe, y consisten en conductas instrumentales y complementarias que gravan a ambas partes por el entrelazamiento jurídico creciente y la obligación de cooperación que cobija tanto al acreedor como al deudor, a fin de que este último cumpla sus cargas obligacionales, y la ejecución de la obligación resulte ventajosa para ambas partes, sin que ninguna abuse de su posición dominante. 
Los deberes secundarios más connotados son los siguientes:

1) Los de protección u obligations de sécurité, exigibles cuando están en riesgo o en juego bienes personales o patrimoniales. Implica desplegar cuidado, cautela y atención para no causar daños y preservar los derechos de las partes y, además, para proteger las negociaciones.

2) Los de información idónea y veraz que excluyan el engaño, los cuales se extienden desde las tratativas o etapa precontractual (cuya infracción daría lugar a la responsabilidad in contrahendo), durante la ejecución del contrato y su etapa posterior, sin desmedro de la carga de autoinformarse que compete a cada una de las partes, posibilitando un adecuado conocimiento de las condiciones de la negociación, de las características del producto o del servicio que se adquiere. En las tratativas resulta relevante la información que cada una de las partes debe entregar, sea para que no se contrate o se haga de manera diversa, salvo causa justificada.

3) Los de consejo o guía, más allá del simple deber de informar, advirtiendo las ventajas y desventajas de ciertas determinaciones, incluyendo la exposición de las situaciones conflictivas que se puedan presentar en el mercado. Van más allá del asesoramiento y asistencia para que puedan cumplirse los fines de la relación contractual.

4) Los deberes de fidelidad que imperan no únicamente en el contrato de mandato, sino que se extienden a la contratación en general a fin de privilegiar la confianza y el cumplimiento contractual para evitar incursionar en conflictos de intereses. Conllevan la exigencia de lealtad a fin de no adelantar negociaciones sin el propósito de concluirlas, no interrumpirlas injustificadamente, pero además, conservar los bienes objeto del contrato.

5) Los deberes de reserva o secreto tocantes con la necesidad de observar discreción con las informaciones, con los datos recibidos durante las tratativas y las conversaciones preliminares para no divulgarlos ni difundirlos en perjuicio de la otra parte, cuya infracción devendrá en la obligación de indemnizar los perjuicios, etc. Todos los deberes se imponen como límites y fronteras en la ejecución de los actos jurídicos y al ejercicio de los derechos, de tal manera que si son sobrepasados o alterados engendran responsabilidad civil, en el ámbito respectivo 
una vez demostrados los correspondientes elementos axiológicos que la integran. Todos o gran parte de ellos, son deberes no previstos por las partes, sin embargo, gobiernan las relaciones obligatorias porque nadie puede utilizar el contrato o el comportamiento jurídico para abusar de sus derechos, para expoliar al otro contratante o para imponer su voluntad o su poder frente al otro extremo, y ante todo, frente al débili20; por el contrario, se atribuye como deber legal y constitucional, colaborar en interés de la ejecución del contrato, no solo en la fase contractual, también en las etapas pre y pos-contractual.

Ahora, quienes opinan que son propiamente poderes secundarios, desconocen que estos también son principales o primarios porque se derivan de las obligaciones y deberes que impone el ordenamiento jurídico, al punto, el código civil francés dispone: "Artículo 1134. Las convenciones legalmente formadas tienen fuerza de ley entre aquellos que las han hecho. No pueden ser revocadas sino por su mutuo consentimiento o por las causas que la ley autoriza. Deben ser cumplidas de buena fe" (Código Civil francés, 2005) y "Artículo 1135. Las convenciones obligan no sólo a lo expresado en ellas, sino también a todas las consecuencias que la equidad, la costumbre o la ley atribuyan a la obligación según su naturaleza" (Código Civil francés, 2005).

Por su parte, el Código Civil italiano impone en su artículo 1374: "el contrato obliga a las partes no sólo a cuanto en él se expresa, sino también a todas las consecuencias que de él se derivan según la ley o, en su defecto, según los usos y la equidad" (Código Civil italiano, 2017); a su vez, el Código Civil español en el artículo 1258 establece que "los contratos se perfeccionan por el mero consentimiento, y desde entonces obligan, no sólo al cumplimiento de lo expresamente pactado, sino también a todas las consecuencias que, según su naturaleza, sean conformes a la buena fe, al uso y a la ley" (Ley de enjuiciamiento civil, 2013, p. 291). La institución también está vertida en algunas constituciones, como la colombiana en el artículo 83 cuando expresamente señala que

20 Carlos Soto, refiere como la aplicación del principio de buena fe, permite corregir los excesos del pacta sunt servanda, evitando abusos en el sistema de contratación masiva, añadiendo: “[...] y con mayor razón en el sistema de contratación masiva o predispuesta, donde la libertad contractual se encuentra limitada en los contratos celebrados en [sic] base a cláusulas generales o ausente en los contratos por adhesión" (Soto, 1997, p. 27). 
las actuaciones de los particulares y de las autoridades públicas deberán ceñirse a los postulados de la buena fe, la cual se presumirá en todas las gestiones que aquellos adelanten ante estas; en instrumentos internacionales como en la Convención de las Naciones Unidas sobre los contratos de compraventa internacional de mercaderías (artículo 7), en los principios UNIDROIT ${ }^{21}$ para la contratación internacional (artículo 1.7), y en los Principios del Derecho Contractual Europeo (PECL) (artículo 1:201).

\subsection{Teoría de los actos propios reflejo de la buena fe en su aspecto objetivo}

El principio de la buena fe también expande su fuerza creadora en la teoría de los actos propios de aplicación constante en las relaciones obligatorias en el marco de los deberes primarios y secundarios de conducta. El principio venire contra factum proprium non valet ${ }^{22}$ tiene su génesis desde Ulpiano (Corpus iuris civilis), cuando se gestó en el vernáculo Derecho Romano, ulteriormente, con Accursio y Bartolo de Sassoferrato, y hoy es el venero de la actual doctrina de los actos propios. Impone tajante la inadmisibilidad de actuar en contra de la propia conducta, estructurándose como límite al derecho subjetivo, de tal modo que en el tráfico jurídico económico y negocial se exige a los contratantes y partes un comportamiento consecuente $\mathrm{y}$, ante todo, coherente, deviniendo en falta de legitimación y carencia de buena fe de un sujeto del vínculo obligacional o de un contratante, reclamar en contra de sus propios actos prohibiéndosele, entonces, alegar judicial o extrajudicialmente el cambio de su comportamiento como hecho fundante de su derecho, todo como exigencia del principio de la buena fe y de lealtad. De tal manera que, en el negocio jurídico moderno nadie puede alterar, cambiar o modificar sus

21 El artículo 1.7 de los principios UNIDROIT sobre los contratos comerciales internacionales refiere: "Artículo 1.7 Buena fe y lealtad negocial. (1) Las partes deben actuar con buena fe y lealtad negocial en el comercio internacional. (2) Las partes no pueden excluir ni limitar este deber." (Instituto Internacional para la Unificación del Derecho Privado, 2012).

22 La Sala de Casación Civil de la Corte Suprema de Justicia de Colombia, en la sentencia de casación del ocho de noviembre de 2013, con ponencia del Magistrado Arturo Solarte Rodríguez, realiza un interesante estudio de la relación entre buena fe y el principio de la doctrina de los actos propios, en el radicado 2006-00041-01, como deber de actuar coherentemente, de tal modo que no se pueden contradecir injustificadamente las conductas anteriores relevantes, ante todo, cuando ese actuar genera expectativas legítimas en los otros, sobre la continuidad de la situación inicial o sobre la permanencia de los precedentes comportamientos. 
designios intempestivamente, porque perjudica las legítimas expectativas de la otra parte o de terceros.

Por ejemplo, si la parte interviniente en un juicio no contrainterroga o no ausculta determinados puntos en su oportunidad, no puede ulteriormente reprochar que esas cuestiones no se investigaron en una prueba testifical; o el contratante que falta a sus deberes primarios o secundarios en el escenario de los negocios jurídicos discute que por haberse incumplido la convención, puede pedir la resolución contractual con fundamento en su propio incumplimiento. La importancia del principio venire contra factum proprium se justifica del mismo modo, porque los otros seres humanos tendrán expectativa o confianza razonable de que una persona actuará observando su comportamiento anterior y no de forma contradictoria en el ámbito contractual. Cuando un sujeto de derecho actúa, surgen expectativas legítimas para los otros sujetos de que esa misma persona obrará de igual modo, sin incoherencias, pues de lo contrario afectará los compromisos adquiridos.

Al respecto, Fueyo Laneri, sostiene: "[...] la doctrina de los actos propios está de tal modo enraizada en el Derecho, como principio general de aplicación amplia, y a la vez como un orden jurídico mayor, que no es patrimonio exclusivo del Derecho Civil o del Derecho Privado. Antes bien, tiene reconocimientos y aplicaciones concretos en las siguientes materias: mercantil, laboral, penal, notarial y contencioso-administrativo, entre otras" (1990, p. 313). Fueyo Laneri, además, señala que para que pueda predicarse la teoría se requiere la concurrencia de los siguientes requisitos: 1) Una conducta anterior relevante y eficaz, esto es vinculante; 2) un acto posterior constitutivo de una pretensión jurídica contradictoria, como nuevo acto, que resulta ahora inadmisible por lo contradictoria ante la anterior; 3) una pretensión nacida de la segunda conducta que, de admitirse, repercutiría en derechos adquiridos por terceros o bien causaría daño y 4) la identidad de los sujetos que actúan y se vinculan en ambas conductas (Fueyo, 1990, p. 313).

\subsection{El Verwirkung y el estoppel}

En el Derecho alemán un instituto análogo se halla en la Verwirkung, que significa caducidad de derechos o retraso desleal. Es una construcción 
jurisprudencial que se originó en el siglo XIX, con antelación a la vigencia del BGB de 1900, extendiéndose a ordenamientos como el suizo, el portugués y el griego, revistiendo los efectos del venire contra factum proprium, con el fin de proteger la confianza por el comportamiento de un titular de un derecho negligente. En términos jurídicos corresponde al tiempo transcurrido para el titular de un derecho durante el cual se ha desentendido, ha sido pasivo o tardío en ejercitarlo, guardando silencio, motivo por el cual, algunos lo asimilan con la caducidad y otros con la prescripción; sin embargo, se trata de una figura diferente. El transcurso del tiempo crea confianza legítima para los demás de que su titular no lo activará o ejercerá, a pesar de haber tenido la posibilidad de hacerlo oportunamente y de imponérselo el ordenamiento, de forma que si al actuar causa perjuicio a los demás sujetos de derecho, porque pudiéndo ejercer el derecho no lo hace, crea confianza en que no lo hará, ni actuará en contra de esta conducta, de modo que, si lo hace, incurre en deslealtad por el retraso, sancionado por el ejercicio tardío porque de alguna manera existió voluntad en renunciar al derecho, pudiendo causar perjuicio, por el ejercicio tardío de la pretensión que afecta la seguridad y confianza, y por tanto, la buena fe en el tráfico jurídico, ante la justificada creencia de que no lo ejercería (Borda, 2005).

La otra institución que se asimila a la teoría de los actos propios, pero con características especiales, es el estoppel anglosajón, comprendido como preclusión, conducta concluyente, aquiescencia o reconocimiento tácito o comportamiento unilateral de una persona natural o jurídica (por ejemplo, los Estados en el ámbito del derecho internacional). Federico Vasallo siguiendo la doctrina del common law, presenta la siguiente definición:

Cuando una persona (representador) ha hecho una representación de los hechos a otra persona (representado) ya sea por sus palabras o los actos de su conducta, o (encontrándose en el deber legal de hablar o actuar) por su silencio o inacción, con la intención (actual o presunta) y con el resultado de inducir al representado, con base a su [buena] fe en dicha representación, a alterar su posición en detrimento propio, el representador, en cualquier litigio que eventualmente tenga lugar entre él y el representado, [incurre en estoppel], está impedido, ante el representado, de hacer, o intentar establecer mediante evidencias, cualquier 
aseveración sustancialmente diferente de su representación previa, si el representado lo objeta en la ocasión oportuna y en la manera apropiada (Vasallo, 2013, p. 182).

Es, en consecuencia, la expresión del consentimiento del sujeto de derecho, que imposibilita que una persona afirme o ejecute ulteriormente algo contrario a la expresión, determinación o manifestación inicial o primaria. Es una presunción que impide y obstaculiza que una persona cambie de opinión, afirme, niegue, o ejecute un hecho determinado, en sentido opuesto al anterior, por cuanto contradice su derecho en perjuicio de los terceros, quienes, confiados en esas expresiones iniciales, contrajeron determinadas obligaciones, de modo que el cambio posterior e intempestivo de actitud perjudica el patrimonio del tercero, por la incoherencia en el sujeto de derecho; en este sentido que el estoppel puede ser opuesto como defensa (Borda, 2005).

El estoppel se asimila a la teoría de los actos propios, tiene aplicaciones en diferentes ramas del derecho y exige los mismos elementos esenciales: 1) una conducta o manifestación primaria o anterior que crea una apariencia de derecho; 2) una conducta posterior contraria fundada en el mismo hecho de la anterior, inadmisible jurídicamente; 3 ) un efecto perjudicial en la otra parte o en los demás sujetos de derecho y 4) unidad en los sujetos jurídicos intervinientes. Finalmente, por virtud de la buena fe, aparece el estoppel como límite y restricción a la incoherencia en la ejecución de actos jurídicos unilaterales o bilaterales.

\section{Armonización del Derecho dentro de un orden público económico mundial que procure la construcción de Estados Sociales de Derecho}

Tanto en el ámbito nacional como en el internacional debe procurarse la armonización jurídica dentro del marco de Estados Sociales de Derecho. La lex mercatoria ${ }^{23} \mathrm{y}$, en general, todos los estatutos nacionales

23 Esta categoría hace referencia a la normativa internacional de estirpe supranacional y, por tanto, autónoma frente a las leyes nacionales de cada Estado, así estos la hayan acogido (como los INCOTERMS y las Reglas UCP 600 de la CCI), con muy frecuente aplicación para regular 
e internacionales deben fincarse en los principios de libertad de contratación ${ }^{24}$, libertad de forma y de prueba ${ }^{25}$, pacta sunt servanda (el contrato es ley para las partes) ${ }^{26}$, primacía de reglas imperativas ${ }^{27}$, naturaleza dispositiva de los principios, internacionalidad y uniformidad ${ }^{28}$, buena fe y lealtad negocial ${ }^{29}$, validez de usos y costumbres ${ }^{30}$, venire contra factum

el tráfico jurídico y las relaciones económicas internacionales. Lex mercatoria o Law Merchant, son términos análogos que aglutinan un cuerpo normativo derivado de los usos y prácticas de comercio internacional respetados universalmente pero, también, engendradas por el continuo ejercicio de la autonomía de la voluntad de los comerciantes y de los empresarios en el ámbito internacional que se han convertido en modelos o normas para la contratación internacional y que son aplicados por comerciantes en el desarrollo de su actividad y por los árbitros en la solución de las correspondientes controversias. Este sistema normativo halla sus antecedentes en el ius gentium, y constituye una respuesta a los vacíos de los códigos civiles del siglo XIX, creados para economías rurales, artesanales y de pequeños burgos o ciudades incipientes dentro del concepto de nación aislada internacionalmente y, por tanto, muchos de ellos casuistas y obsoletos, incapaces de advertir la trascendencia del comercio internacional y de la economía globalizada.

24 El artículo 1.1 de los Principios UNIDROIT sobre los contratos comerciales internacionales, señala: "Artículo 1.1 Libertad de Contratación. Las partes son libre para celebrar un contrato y para determinar su contenido" (UNIDROIT, 2010, p. 1).

25 El artículo 1.2 de los Principios UNIDROIT sobre los contratos comerciales internacionales, señala: "Artículo 1.2 Libertad de Forma. Nada de lo expresado en estos Principios requiere que un contrato, declaración o acto alguno deba ser celebrado o probado conforme a una forma en particular. El contrato puede ser probado por cualquier medio, incluidos los testigos" (UNIDROIT, 2010, p. 1).

26 El artículo 1.3 de los Principios UNIDROIT sobre los contratos comerciales internacionales, señala: "Artículo 1.3 Carácter vinculante de los contratos. Todo contrato válidamente celebrado es obligatorio para las partes. Sólo puede ser modificado o extinguido conforme a lo que él disponga, por acuerdo de las partes o por algún otro modo conforme a estos Principios" (UNIDROIT, 2010, p. 2).

27 El artículo 1.4 de los Principios UNIDROIT sobre los contratos comerciales internacionales, apunta: "Artículo 1.4 Normas de carácter imperativo. Estos Principios no restringen la aplicación de normas de carácter imperativo, sean de origen nacional, internacional o supranacional, que resulten aplicables conforme a las normas pertinentes de derecho internacional privado" (UNIDROIT 2010, p. 2).

28 El artículo 1.6 de los Principios UNIDROIT sobre los contratos comerciales internacionales, determina: "Artículo 1.6 Interpretación e integración de los Principios. 1) En la interpretación de estos Principios se tendrá en cuenta su carácter internacional así como sus propósitos, incluyendo la necesidad de promover la uniformidad en su aplicación. 2) Las cuestiones que se encuentren comprendidas en el ámbito de aplicación de estos Principios, aunque no resueltas expresamente por ellos, se resolverán en lo posible según sus principios generales subyacentes" (UNIDROIT, 2010, p. 2).

29 Ver nota 25.

30 El artículo 1.9 de los Principios UNIDROIT sobre los contratos comerciales internacionales, impone: "Artículo 1.9 Usos y Prácticas. (1) Las partes están obligadas por cualquier uso en que hayan convenido y por cualquier práctica que hayan establecido entre ellas. (2) Las partes están obligadas por cualquier uso que sea ampliamente conocido y regularmente observado en el comercio internacional por los sujetos participantes en el tráfico mercantil de que se trate, a menos que la aplicación de dicho uso sea irrazonable" (UNIDROIT, 2010, p. 2). 
proprium (prohibición de actuar en contra del acto propio) ${ }^{31}$. Sin embargo, el norte y criterio fundamental en la aplicación de todos estos principios ha de ser la construcción de un Estado Social de Derecho que procure relaciones de equidad entre los sujetos de derecho entrelazados por el vínculo obligacional, entre los contratantes, entre las nacionalidades y con una decidida protección de los derechos del usuario, del consumidor, de la víctima y, en general, del sujeto interviniente en la relación obligacional que se encuentra en posición debilitada e inerme por fuerza de los hechos, de las coyunturas políticas, de la carencia de información y de capital y por carecer de poder político y económico.

Esto implica la necesidad de forjar un nuevo Derecho Obligacional con carácter obligatorio como base de las relaciones jurídicas, económicas y sociales como un mecanismo para facilitar los mercados internos y externos pero, ante todo, para un fácil acceso a los productos de la sociedad actual y pronta satisfacción de las necesidades de todos los seres humanos, potenciando instrumentos para dar tratamiento igualitario a todos los consumidores. Los mercados globalizados demandan monedas únicas, medidas arancelarias y aduaneras comunes, disminución de las barreras, etc., pero todo ello resulta imposible si se continúa con diversidad de contrataciones locales o regionales ajenas a la armonización; todo será quimérico si no se adoptan nociones y principios comunes con un marco conceptual jurídico común, tanto desde el punto de vista técnico como desde la perspectiva ideológica.

Los crecientes procesos de globalización y de internacionalización de la economía y de los negocios imponen la formación de un derecho global o un universal law, en el cual haya influencia del ius gentium ${ }^{32}$ y

31 El artículo 1.8 de los Principios UnIDROIT sobre los contratos comerciales internacionales, señala: "Artículo 1.8 Comportamiento contradictorio. Venire contra factum proprium. Una parte que no puede actuar en contradicción a un entendimiento que ella ha suscitado en su contraparte y conforme al cual esta última ha actuado razonablemente en consecuencia y en su desventaja" (UNIDROIT, 2010, p. 2).

32 Ius gentium o derecho de gentes, es una categoría de origen romano referida a las instituciones y normas flexibles que se aplicaban a los extranjeros o peregrinos que no ostentaban la ciudadanía romana y a quienes no se destinaba el derecho civil ni su formalismo, luego se extendió a las colonias y provincias romanas y, desde entonces a hoy, corresponde a un conjunto de disposiciones escritas o no, de derecho internacional público que abordan temas como los derechos a la guerra y la paz o instituciones con pretensión universal para regular las relaciones entre Estados o entre las personas de las diferentes nacionalidades. Inicialmente se consideró como parte del derecho privado llegando a concebirse como referido a los derechos entre los 
del ius cogens ${ }^{33}$, que recoja los principios del derecho convencional, de la jurisprudencia y de las costumbres internacionales en materia de derechos humanos, aplicable a los hechos, actos y negocios jurídicos del derecho a la integración y de la responsabilidad internacional adaptables al ámbito obligacional. Dentro de este dominio no puede ignorarse el ius commune $^{34}$, de gran aplicación en los negocios jurídicos internacionales, normatividad que poco a poco se torna obligatoria para los Estados y personas de todo el mundo.

Algunas aproximaciones a tendencias recientes de unificación con carácter multilateral las encontramos en el Instituto Internacional para la Unificación del Derecho Privado (UNIDROIT), la Comisión de Naciones Unidas para el Derecho Mercantil Internacional (Cnudmi o también

diferentes Estados. Entre sus teóricos se encuentran Hugo Grocio, Cristian Wolff y Jean Bodín, quien lo acerca al derecho humanitario.

33 Ius cogens significa derecho coercitivo, impositivo, obligatorio o superior a la voluntad de cada Estado, cuyo núcleo central es la idea de "humanidad" y por ello se equiparan como peremptory norms. Se trata del derecho internacional público que compendia normas internacionales indisponibles, imprescriptibles, obligatorias e imperativa que no pueden ser excluidas ni alteradas por la voluntad individual de los Estados, por amparar con efectos erga omnes derechos colectivos o bienes universales, que obligan a todos los Estados, y por tanto, constituyen disposiciones que gozan de preeminencia jerárquica. El art. 53 de la Convención de Viena de 1969, que regula el derecho de los tratados, modernamente es la norma fundante de este cuerpo jurídico porque sanciona con nulidad los actos jurídicos internacionales que infrinjan normas internacionales imperativas y, que como un mínimum, se imponen a todos los Estados con carácter general, postulando un control de inconvencionalidad de naturaleza universal contra los actos o negocios jurídicos internacionales que las quebranten, mecanismo reafirmado luego en el art. 64 del mismo Estatuto.

Dentro de ese conjunto normativo se hallan, enunciativamente: 1) la prohibición de ataques contra civiles y el principio de distinción entre civiles y militares, 2) el principio de proporcionalidad en la utilización de armas en las conflagraciones internacionales (cláusula Martens) y 3 ) el principio de prohibición de la tortura, observancia de garantías básicas (presunción de inocencia) y protección de la vida. En fin, a manera de compendio, encontramos el derecho a la igualdad, la autodeterminación de los pueblos, la prohibición del uso de la fuerza, solución pacífica de controversias, la no-intervención, la protección de derechos humanos, la buena fe internacional en el cumplimiento de obligaciones, la cláusula pacta sunt servanda. Algunos de sus teóricos son Hugo Grocio y Emmerich Vattel.

34 Es el derecho que se aplica por regla general a la mayoría de asuntos o de personas ante la ausencia de un ordenamiento o régimen especial, por ello la denominación de "común". Para un sector, es el derecho civil como régimen diferente al comercial, en cuanto direcciona la actividad de quienes no son comerciantes, pero que de todas formas corresponde a un sistema jurídico con aplicación residual en el derecho mercantil o ante la ausencia de regímenes especiales o forales. En ese sentido como traducción de common law, es decir, derecho común, se asimila con el derecho civil. Halla sus antecedentes en el derecho justinianeo (corpus iuris civilis), ampliado por el canónico (corpus iuris canonici) y los aportes de los glosadores y postglosadores, todo como un producto de raigambre cultural. 
conocida como Uncitral), la Cámara de Comercio Internacional (CCI) y los diversos Tratados Internacionales de Comercio.

Un gran esfuerzo desde el punto de vista institucional y normativo para la armonización se gestó con la creación de UNIDROIT, organización que cuenta con más de sesenta y tres Estados miembros. Fue creado en 1926, bajo el auspicio de la Liga de las Naciones y a él pertenece Colombia desde el diecinueve de abril de 1940. En 1994 publicó Los principios de UNIDROIT sobre contratos internacionales comerciales. Es una organización intergubernamental independiente con sede en Roma, $\mathrm{cu}^{-}$ yo objetivo es estudiar las necesidades y los métodos para modernizar, armonizar y coordinar el derecho privado. Contribuye en la redacción y aprobación de normativas de derecho privado aplicables a los países miembros y entre sus avances se destacan los principios generales sobre derecho privado, para las áreas mercantil y civil entre Estados y grupos de Estados. Su misión central es formular los instrumentos, principios y normas de derecho uniforme, para alcanzar la armonización del derecho, mediante principios aplicables en la legislación nacional. Entre sus instrumentos más importantes se hallan la Convención de la Formación de Contratos para la Venta Internacional de Mercaderías (La Haya), la Convención sobre Arrendamiento Financiero Internacional (Ottawa), la Convención al Factoraje Internacional (Ottawa) y la Convención de los Objetos Culturales Robados o Ilegalmente Exportados (Roma).

Otro de los organismos que caminan por la misma senda es la Comisión de las Naciones Unidas para el Derecho Mercantil Internacional (CNUDMI o también conocida por sus siglas en inglés, UNCITRAL). La Asamblea General de las Naciones Unidas, el diecisiete de diciembre de 1966 mediante resolución 2205 creó la CNUDMI como cuerpo consultivo de la ONU con el fin de armonizar y unificar el derecho mercantil internacional, mejorar el comercio internacional y adoptar un sistema legal de estándares y reglas que lo faciliten, por medio de convenciones o convenios, leyes modelo, guías legislativas y disposiciones modelo.

También debe destacarse la CCI, Cámara de Comercio Internacional, como organización empresarial mundial, creada en 1919 con el fin de promover el crecimiento y la prosperidad por medio de sugerencias a la Organización Mundial del Comercio (OMC), promocionar alianzas con las ONU y sus agencias y fijar las reglas en materia de los Incoterms 
(Internacional Commercial Terms), que son reglas internacionales para la interpretación de los términos comerciales fijados por las partes contratantes en el ámbito internacional.

Las instituciones reseñadas son apenas unas de las principales manifestaciones en la globalización del derecho, ante todo en aspecto económico, en procura de materializar la armonización jurídica. Estas tendencias, empero, de alguna manera implican replantear el concepto de soberanía nacional, por cuanto todos esos fenómenos en su conjunto, erosionan instituciones y conceptos políticos y económicos clásicos, así como la categoría contemporánea de Estado Nación, que apoyado por los contractualistas y por el art. 1134 del clásico Código Civil francés sustituyó el poder personalizado y arbitrario del monarca. L'État c'est moi por lex fons regem.

En efecto, hay crecientes avances de la lex mercatoria y, del mismo modo, omnipotencia e imposición de entidades y organismos transnacionales, por ejemplo, el Fondo Monetario Internacional y el Banco Mundial apalancan la transnacionalización y sofocan Estados modernos imponiéndoles políticas monetarias, fiscales y sociales. Tendencias y organizaciones como el Acuerdo General sobre Aranceles y Comercio (GATT) en 1947 gestaron la regulación del comercio internacional para luchar contra aranceles proteccionistas y las barreras no arancelarias, impulsando los principios de trato de la nación más favorecida y del trato nacional en búsqueda de la equidad e igualdad, contribuyendo a la reformulación del concepto de frontera nacional. Todo ese movimiento envolvente se ha fortalecido con los TLC, con la incentivación de los sistemas de mediación internacional: conciliación, arbitraje y mediación y con toda una serie de nuevos acuerdos regionales.

Ahora bien, este principio choca expresamente con el acentuado nacionalismo jurídico y cultural acendrado en algunas zonas de Europa y Asia, circunstancia geopolítica que demanda conocer las instituciones de cada región para realizar diálogos y acuerdos jurídicos, hallando y concertando los puntos comunes que faciliten la armonización. Pero este obstáculo no es del todo negativo, porque armonización no puede significar la desaparición íntegra de todo el derecho interno o autóctono de las naciones, puesto que hay problemas culturales y locales que no pueden ser resueltos con disposiciones de otras regiones o países. Exis- 
ten elementos comunes para todos los ámbitos jurídicos pero al mismo tiempo, hay unos regionales y locales que no pueden ser aniquilados, sino vistos en términos de diálogo intercultural.

\section{Necesidad de contemplar el impacto de nuevas realidades jurídicas}

No puede desconocerse que surgen nuevos sujetos de derecho con vigorosa y decisiva importancia para la supervivencia de la especie humana; entre ellos "La Humanidad", así como entidades jurídicas como la Tierra, el agua ${ }^{35}$, la naturaleza y los animales. Por ejemplo, siendo el agua un derecho fundamental básico, en lugar de protegerla y de luchar contra la contaminación y destrucción de sus fuentes, parlamentos y autoridades invierten recursos en debates políticos y jurídicos insulsos y diletantes sobre la naturaleza y estatus jurídico de lo hídrico. La comunidad jurídica y política y los demás estamentos de la sociedad, en bloque, deben apostar por resguardarla, descontaminarla y conservarla adoptando políticas concretas y decisivas porque, tratándose de una prerrogativa esencial, al menos debería garantizarse su acceso para todos los habitantes de la tierra.

Estas nuevas realidades, aparentemente inocuas y sin sentido para la dogmática jurídica, demandan un derecho global, justo, democrático y libre, que propenda por la protección de todos los seres humanos, de un medio ambiente saludable que perdure la existencia de los vivientes, que tenga como objetivos inmediatos la dignidad de la persona, su libertad y su autonomía, que sobredimensione la razón jurídica sobre la fuerza, que potencie la igualdad, la solidaridad, los principios de integración y la defensa de los derechos fundamentales mínimos, sobre las tendencias

35 El agua, con frecuencia se ignora, es una condición de sobrevivencia, no contemplamos que además de derecho fundamental es una realidad jurídica que debe ser causa común y universal en procura de su protección, como deber de todos los sujetos de derecho y de los gobiernos. Muchas veces, quienes disfrutamos de agua en abundancia, afectamos o matamos a las personas comunes y corrientes cuando la malgastamos, la contaminamos y descuidamos su defensa y protección. Ignoramos cuanto representa para nuestra vida diaria, desdeñamos lo realmente necesaria para vivir, para la subsistencia, la industria, la agricultura, la ganadería, el transporte, para la producción de alimentos y de energía. Sin embargo, en contra de necesidades vitales universales destruimos directa o indirectamente las fuentes hídricas. 
que abogan por el armamentismo y por el desarrollo industrial o económico destructor del planeta y de la biosfera. Se trata de una visión que se comprometa con el resguardo y defensa total de los valores, principios y derechos elementales para todos los seres humanos en cualquier rincón del mundo con independencia de su nacionalidad, clase social o condición; edificando un derecho con justicia material que combata la injusticia en la comunidad internacional. En este sentido, cobran capital importancia las obligaciones y los derechos colectivos u homogéneos porque aglutinan intereses individuales idénticos o semejantes, como multiplicidad de derechos afectados en forma similar.

En este marco, no se trata de apostar propiamente por el Estado de "bienestar", concepto que nace de las entrañas del liberalismo clásico anglosajón que ha procurado combatir el capitalismo salvaje ofreciendo la satisfacción de algunos derechos fundamentales como la salud y otros, adoptando políticas públicas de subsidios para la educación, la vivienda, para el desempleo, etc. pero sin solucionar los graves problemas sociales como los de la enorme brecha entre pobres y ricos, ni los económicos ni los ambientales que aquejan a la humanidad. Más bien, se trata de encauzar el planeta tierra, sus realidades y todos sus habitantes desde la relación obligatoria con contenido de justicia y de ética, en diálogo persistente con la conservación del medio ambiente y de la naturaleza para construir el modo del "buen vivir", que profundiza lo humano y lo natural, lo justo y lo resiliente, desechando el consumo obsesivo y destructivo del universo. Se impone, entonces, desde el derecho hacer fuerza con otros quehaceres teóricos para proyectar una civilización que permita la convivencia del hombre y la naturaleza, la existencia de relaciones obligatorias equilibradas entre los propios seres vivientes, y entre estos y el medio ambiente, sin menoscabar la necesidad de un desarrollo racional; en fin, se trata de la visión del mundo y del hombre como parte de un entorno natural y social en continuo progreso dentro de un marco de justicia social.

\section{Referencias}

Austin, J. (2010). The Providence of Jurisprudence Determined. Londres: Gale, Making of Modern Law. 
Borda, A. (2005). La teoría de los actos propios. Buenos Aires: Lexis Nexis Abeledo-Perrot.

Comisión de las comunidades europeas. (2017). Principios sobre el derecho contractual europeo. Recuperado de http://eur-lex.europa.eu/legal-content/ES/ TXT/PDF/?uri=CELEX:52001DC0398\&from=ES

Corte Constitucional, Sala Plena. (2 de junio de 1994). Sentencia C-265. Magistrado Ponente Dr. Alejandro Martínez Caballero.

Corte Constitucional. (16 de noviembre de 1995). Sentencia C-524/95. Magistrado Ponente Dr. Carlos Gaviria Díaz.

Corte Constitucional. (7 de septiembre de 2004). Sentencia C-865. Magistrado Ponente Dr. Rodrigo Escobar Gil.

Corte Constitucional. (6 de noviembre de 2008). Sentencia T-1096. Magistrada Ponente Dra. Clara Inés Vargas Hernández.

Corte Constitucional. (23 de mayo de 2013). Sentencia C-313. Magistrado Ponente Dr. Gabriel Eduardo Mendoza Martelo.

Corte Suprema de Justicia, Sala Civil. (20 de mayo de 1936). Magistrado Ponente Dr. Eduardo Zuleta Ángel.

Corte Suprema de Justicia, Sala Civil. (30 de abril de 2009). Expediente No. 258993193992199900629 01. Magistrado Ponente Dr. Pedro Octavio Munar Cadena.

Corte Suprema de Justicia, Sala Civil. (8 de noviembre de 2013). Expediente No. 2006-00041-01. Magistrado Ponente Dr. Arturo Solarte Rodríguez.

Concepción, J. L. (2009). Derecho de Daños. (3. a ed.). Barcelona: Editorial Bosch. Espín, D. (1955). Los límites de la autonomía de la voluntad en el Derecho privado. Anales de la Universidad de Murcia Derecho, XIII(1), 9-59.

Ferri, L. (1969). La Autonomía Privada. Madrid: Editorial Revista de Derecho Privado.

Fueyo, F. (1990). Instituciones de Derecho Civil Moderno. Santiago: Editorial Jurídica de Chile.

Ibañez, J. E. (1998). Los derechos de los consumidores y usuarios, fundamentos constitucionales y desarrollo legal. En Politica y Derecho del Consumo (pp. 59135). Bogotá: El Navegante Editores.

Instituto Internacional para la Unificación del Derecho Privado. (2012). Los principios UNIDROIT sobre los contratos comerciales internacionales 2010. Madrid: La ley. Kelsen, H. (2009). Teoría Pura del Derecho. Buenos Aires: Eudeba.

López, J. (2003). Derechos del Consumidor: Consagración Constitucional en Latinoamérica $e-$ Mercatoria, 2(2), 1-42. 
Organización de las Naciones Unidas. (2016). Acuerdo de París. Recuperado de http://unfccc.int/resource/docs/2015/cop21/spa/109s.pdf

Organización de las Naciones Unidas, Asamblea General. Resolución 2398(XXIII), Problemas del medio humano (3 de diciembre de 1968). Recuperado de http://www.un.org/es/comun/docs/?symbol=A/RES/2398(XXIII)\&Lang $=$ SEArea $=$ RESOLUTION

Organización de las Naciones Unidas, Asamblea General. Resolución 39/248, Protección del consumidor (9 de abril de 1985). Recuperado de http:// www.un.org/es/comun/docs/?symbol=A/RES/39/248ELang=S

Organización de las Naciones Unidas, Asamblea General. Resolución 2205(XXI), Establecimiento de la Comisión de las Naciones Unidas para el Derecho Mercantil Internacional (17 de diciembre de 1966). Recuperado de: http:// www.un.org/es/comun/docs/?symbol=A/RES/2205(XXI)

Reino de España. (1978). Constitución Española. Recuperado de http://www. senado.es/web/conocersenado/normas/constitucion/detalleconstitucioncompleta/index.html\#t1c3

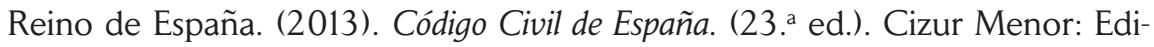
torial Aranzadi S.A.

República de Colombia. (2013). Constitución Politica de Colombia de 1991. Bogotá: Consejo Superior de la Judicatura.

República de Colombia. (2011). Estatuto del consumidor. Ley 1480 de 2011. Recuperado de https://issuu.com/quioscosic/docs/do_48220_ley_1480_12_10_11_ estatuto

República de Colombia. (2014). Código Civil. Medellín: Librería Jurídica Sánchez Ltda.

República de Colombia. (2014). Código de Comercio. Medellín: Librería Jurídica Sánchez Ltda.

República Federal de Alemania. (2008). Código Civil Alemán (BGB) y Ley de Introducción al Código Civil, Boletín Oficial Federal, Barcelona: Marcial Pons.

República Francesa. (2005). Código Civil Francés. Barcelona: Marcial Pons.

República Italiana. (2017). Código Civil de Italia. Recuperado de: http://www. wipo.int/wipolex/es/text.jsp?file_id=430550.

Savigny, F. K. (2004). Sistema de derecho romano actual. Pamplona: Analecta. Soto, C. (1997). Un estudio comparado de las cláusulas generales de contratación en los sistemas jurídicos peruano y argentino. Revista del Magister en Derecho Civil, 23(229).

Soto, C. (2003). La autonomía privada y la buena fe como fundamento de la obligatoriedad del contrato. Vniversitas, 52(106), 519-562. 
Unión Europea. (1992). Tratado de Maastricht. Recuperado de https://europa. eu/european-union/sites/europaeu/files/docs/body/treaty_on_european_ union_es.pdf.

Unión Europea. (1999). Tratado de Amsterdam. Recuperado de https://europa.eu/ european-union/sites/europaeu/files/docs/body/treaty_of_amsterdam_es.pdf

Unión Europea. (2004). Tratado por el que se establece una Constitución para Europa. Recuperado de https://europa.eu/european-union/sites/europaeu/files/ docs/body/treaty_establishing_a_constitution_for_europe_es.pdf

Unión Europea. (2004). Directiva 2004/35-CE del Parlamento Europeo y del Consejo de 21 de abril de 2004, sobre la responsabilidad medioambiental en relación con la prevención y reparación de daños medioambientales. Recuperado de http:// eur-lex.europa.eu/LexUriServ/LexUriServ.do?uri=OJ:L:2004:143:0056:0 075:es:PDF

Vasallo, F. (2013). El estoppel: Dificultades para definir una regla en derecho internacional y el rol deslucido de la Corte Internacional de Justicia. Revista Lecciones y Ensayos, (91), 181-191. 